\title{
Carbon Footprint Status, Climate Change Mitigation Awareness and Education for Sustainable Development Perceptions of School Principals in the Island of Panay: Bases for an Eco-school Toolkit
}

\author{
Ju-im T. Jimlan \\ Tamalagon Integrated School, Department of Education, Division of Aklan, Philippines \\ $\triangle$ Corresponding Author: Ju-im T. Jimlan, E-mail: juimjimlan888@yahoo.com
}

\section{ARTICLE INFORMATION}

Received: December 22, 2020

Accepted: February 14, 2021

Volume: 3

Issue: 1

DOI: 10.32996/jweep.2021.3.1.3

\section{KEYWORDS}

Eco-school Toolkit, Carbon Footprints, Climate Change,

Sustainable Development

\section{ABSTRACT}

The study aimed to develop an eco-school toolkit based on the assessed levels of carbon footprint status, climate change mitigation awareness and education for sustainable development perceptions of principals in the Island of Panay for the School Year 2019-2020. The researcher employed mixed method research design: quantitative and qualitative approach. A survey was conducted to the randomly selected 210 samples using the researcher-made questionnaires, and two sessions of focus group discussions were conducted to the Philippine - Open Government Partnership (P-OGP), National Executive Coordinating Council (NECC) and international philanthropists. The Eco-School Toolkit was adopted from the 4Ds Training Cycle Map Process by Samuel Phil (2010). The data was statistically interpreted through frequency counts, percentage, mean, standard deviation, Analysis of Variance, Pearson correlation coefficient at 0.05 level of significance. The results shows that RPMS-PPST rating revealed that principals with "outstanding" and "very satisfactory" ratings consume maximum energy and living a "carbon-unfriendly lifestyle" resulting to an increase in the carbon footprint status. This may create negative impressions among teachers that "outstanding" or "very satisfactory" principals are not manifesting carbon friendly habits, attitudes, practices and cultures. On the other hand, geographical location, age, sexual orientation and RPMS PPST Rating will not affect climate change mitigation awareness of principals. Further, geographical location, age, sexual orientation and RPMS PPST Rating will not affect education for sustainable development perceptions of principals. Carbon footprint status is a significant indicator of education for sustainable development. Climate change mitigation awareness is a significant indicator of education for sustainable development. The school principals' carbon footprint status influences their climate change mitigation awareness and the climate change mitigation awareness influences their education for sustainable development perceptions; and education for sustainable development perceptions influences their carbon footprint status. The interconnectedness, interrelationships and interrelatedness of carbon footprint status, climate change mitigation awareness and education for sustainable development perceptions may create ecological foundations for school principals to be eco-friendly leader, serving an eco-friendly school and promoting an eco-friendly community for an eco-friendly nation.

\section{Introduction}

Reducing carbon footprint is important; however, it is limited if not coupled with reducing the toxic emissions from schools. This is something school principals are supposed to teach and something all teachers and students regardless of their beliefs, should practice. The carbon footprint can be defined as the total amount of carbon dioxide and other greenhouse gases, emitted over

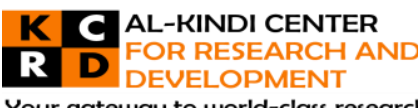

Your gateway to world-class research

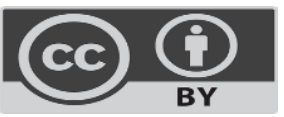

Published by Al-Kindi Center for Research and Development. Copyright (c) the author(s). This open access article is distributed under a Creative Commons Attribution (CC-BY) 4.0 license 
the full life cycle of a product, service, or event. Carbon dioxide is a type of greenhouse gas. In other words, it's a kind of gas that traps heat within the Earth.

The Philippines total greenhouse gas emissions in 2012 were 157.6 million metric tons of carbon dioxide equivalent, totaling 0.33 percent of global greenhouse emissions. The 54 percent of greenhouse gas emissions came from the energy sector, followed by the agriculture, industrial processes, waste, and land-use change, and forestry sectors which contributed 33 percent, 8 percent, 7 percent, and -1 percent respectively to greenhouse gas emissions. In the PRE-SONA 2019, the Department of Environment and Natural Resources secretary Cemato (2019) reiterated that the Philippines has a very small carbon footprint even among countries of a similar level of development.

Nevertheless, climate change occurs when changes in the Earth's climate system result in new weather patterns that last for at least few decades and maybe for millions of years. As reported by ADB (2010), the Philippines is highly exposed to hazards created by weather events; and, climate change will exacerbate this through an increase in extreme weather events, changes in temperature, shifts in rainfall patterns, and sea level rise. Natural disasters already account for more than 0.5 percent of gross domestic product (GDP) annually and climate change is expected to increase these losses further, making it a development issue rather than one confined to environmental concerns. Climate change will, however, also make new financing available for a more sustainable low-carbon economy and allow affected countries to take adaptation measures (ADB, 2010).

The context of climate change became even more bothersome because of globalization and digitalization which have rapidly connected the world. The world becomes increasingly complex and uncertain. In addition to these mega-trends, humanity is altering the planet's climate, animals, and landscapes in unprecedented ways, and threatening all life on earth. People have entered the Anthropocene - a new geological area shaped by humanity.

Above all, schools need new perspectives to be able to understand the rapidly changing world. To realize this ambition, a new approach to education is needed. Sustainability education provides this alternative approach, aiming to educate students as global citizens for sustainable development.

Education for Sustainable Development (ESD) was a United Nations program which aims to equip current and future generations to meet their needs using a balanced and integrated approach to the economic, social, and environmental dimensions of sustainable development (TSDEP, 2014). This promotes the development of the knowledge, skills, understanding, values, and actions which are necessary to create a sustainable world, which ensures environmental protection and conservation, promotes social equity, and encourages economic sustainability. ESD is mandated which formal school system must comply with the provisions of the Philippine Constitution, Presidential Decree, and several Memorandum from the Department of Education such as Presidential Decree 1152, Republic Act No. 9512, DepEd Order No. 52, s. 2011, DepEd Order No. 72, s. 2003, and DepEd Memorandum No. 133, s. 2014. It is a challenge to educators as well to the school administrators to cultivate political, social, and moral responsibility of caring for the environment of the students in order to attain and sustain the benefits of engaging in sustainable development. In compliance with these provisions, most of the schools, not only in the Island of Panay, Philippines, are actively engaging their students in some sustainable practices like waste segregation and energy conservation. There are also income-generating projects like selling plastic bottles and papers that help students practice 3R's, i.e., reduce, reuse, and recycle.

Based on the above-mentioned scenario in carbon footprint status, climate change mitigation awareness, and education for sustainable development perceptions, the researcher embarked on the development of an eco-school toolkit which focuses on advocacy that promotes environmental protection and preservation. This toolkit is necessary to bridge any organizational gap and increase the level of awareness in terms of carbon footprint status, enhance the climate change mitigation strategies, and improve the perceptions of education for sustainable development for economic, social, and environmental progress. Hence, this study was conducted.

The eco-school toolkit was anchored on EARTHANS -The Guardians of Nature by Caranto (2019). This provides informative and engaging content to the youth, students, and other community members to promote greater awareness on crucial environmental issues. This study was designed to foster better understanding among different sectors regarding these global challenges as well as tackle the relevant measures that can be used to mitigate their effects. Additionally, the material further inspires the millennial to be the stewards of the Earth who will help to protect the planet through ecologically, responsible actions and collaborative efforts. It supports the mandate of Department of Education with DepEd Order 52, s. 2011 which calls for strengthening environmental education in public and private schools. The Department of Education, in view of the pressing global concerns and issues on environment, urges schools to lead the role on environmental awareness by enhancing environmental education and by pursuing effective school-based activities that seek to preserve and protect the environment 
which is in pursuant with Republic Act No. 9512: An Act Promoting Environmental Education and for Other Purposes.

The study aimed to develop an eco-school toolkit based on the assessed levels of carbon footprint status, climate change mitigation awareness and education for sustainable development perceptions of principals in the Island of Panay for the School Year 2019-2020. Specifically, this sought to determine the level of carbon footprint status, level of climate change mitigation awareness, and level of education for sustainable development perceptions of principals as an entire group and when they are grouped according to age, sexual orientation, geographical location and RPMS-PPST rating.

The results of the study were perceived to provide significant contributions to the school principals, teachers, students, DepEd planners, administrators and supervisors, parents, stakeholders, and future researchers. Science teachers will be guided on the importance of environmental preservation and protection utilizing the eco-school toolkit and give them the drive to integrate carbon footprint, climate change mitigation, and education for sustainable development concepts in their lessons and countercheck the effectiveness of implementation in the school level. Moreover, school principals will awaken and convince them to exert extra efforts in promoting green education among the students and teachers. It encourages them to enhance their naturalist instincts which are needed for a wholistic management for sustainable development in education. Also, students will be aware through this study their roles in promoting education for sustainable development and parents will realize their roles as prime educators of their children in terms of responsibility to protect nature for the future. Further, Department of Education can be motivated to deliver an eco-friendly and more realistic perceptions and attitudes towards the crucial problems in the environment and will also guide top managers to achieve an interconnectedness mindset that considers components of nature as essential for sustainability.

\section{Literature Review}

The concept of carbon footprint originates from ecological footprint discussion developed by William E. Rees and Mathis Wackernagel in the 1990s. It was then an accounting approach that compares how much people demand compared to what the planet can renew. This allows to assess the number of "earths" that would be required if everyone on the planet consumed resources at the same level as the person calculating their ecological footprint. The carbon Footprint is one part of the ecological footprint. Grub and Ellis (2010) defined carbon footprint as a measure of the amount of carbon dioxide emitted through the combustion of fossil fuels. In the case of business organization, it is the amount of carbon dioxide emitted either directly or indirectly as a result of its everyday operations. It also might reflect the fossil energy represented in a product or commodity reaching market (Grub and Ellis 2010). According to Berners-Lee and Clark (2010), when talking about climate change, footprint is a metaphor for the total impact that something has. And carbon is shorthand for all the different greenhouse gases that contribute to global warming. The term, therefore, is a shorthand to describe the best estimate of the full climate change impact of something. That something could be anything - an activity, an item, a lifestyle, a company, a country or even the whole world (Berners-Lee and Clark, 2010).

A carbon footprint is historically defined as the total emissions caused by an individual, event, organization, or product, expressed as carbon dioxide equivalent. Greenhouse gases (GHGs), including carbon dioxide, can be emitted through land clearance and the production and consumption of food, fuels, manufactured goods, materials, wood, roads, buildings, transportation and other services (Collins, 2011).

Collins (2011) however, mentioned that in most cases, the total carbon footprint cannot be exactly calculated because of inadequate knowledge of and data about the complex interactions between contributing processes, including the influence of natural processes that store or release carbon dioxide. For this reason it is suggested to define the carbon footprint as: A measure of the total amount of carbon dioxide $\left(\mathrm{CO}_{2}\right)$ and methane $\left(\mathrm{CH}_{4}\right)$ emissions of a defined population, system or activity, considering all relevant sources, sinks and storage within the spatial and temporal boundary of the population, system or activity of interest. Using the relevant 100-year global warming potential, it is calculated as carbon dioxide equivalent.

For EPA (2014), carbon footprint is the total amount of greenhouse gases that are emitted into the atmosphere each year by a person, family, building, organization, or company. A person's carbon footprint includes greenhouse gas emissions from fuel that he or she burns directly, such as by heating a home or riding in a car. It also includes greenhouse gases that come from producing the goods or services that the person uses, including emissions from power plants that make electricity factories that make products and landfills where trash gets sent.

As stated in Seth (2017), an individual's, nation's, or organization's carbon footprint can be measured by undertaking a GHGemissions assessment, a life cycle assessment, or other calculative activities denoted as carbon accounting. Once the size of a carbon footprint is known, a strategy can be devised to reduce it, e.g. by technological developments, energy 
efficiency improvements, better process and product management, changed Green Public or Private Procurement (GPP), carbon capture, consumption strategies, carbon offsetting and others (Seth, 2017).

According to Wynes (2017), to calculate for personal carbon footprints several free online carbon footprint calculators exist including a few supported by publicly available peer-reviewed data and calculations including the University of California, Berkeley's Cool Climate Network research consortium and Carbon Story. These websites ask you to answer more or less detailed questions about your diet, transportation choices, home size, shopping and recreational activities, usage of electricity, heating, and heavy appliances such as dryers and refrigerators, and so on. The website then estimates your carbon footprint based on your answers to these questions. A systematic literature review was conducted to objectively determine the best way to calculate individual/household carbon footprints. This review identified 13 calculation principles and subsequently used the same principles to evaluate the 15 most popular online carbon footprint calculators. A recent study's results by Carnegie Mellon's Christopher Weber found that the calculation of carbon footprints for products is often filled with large uncertainties. The variables of owning electronic goods such as the production, shipment, and previous technology used to make that product, can make it difficult to create an accurate carbon footprint. It is important to question, and address the accuracy of Carbon Footprint techniques, especially due to its overwhelming popularity (Wynes, 2017).

In the case of industry, product or service, calculating the carbon footprint is a complex task. One tool industry uses is Life-cycle assessment (LCA), where carbon footprint may be one of many factors taken into consideration when assessing a product or service. The International Organization for Standardization has a standard called ISO 14040:2006 that has the framework for conducting an LCA study. Another method is through the Greenhouse Gas Protocol, a set of standards for tracking GHG emissions (Jones, 2011).

Jones (2011) stated that predicting the carbon footprint of a process is also possible through estimations using the above standards. By using Emission intensities/Carbon intensities and the estimated annual use of a fuel, chemical, or other inputs, the carbon footprint can be estimated while a process is being planned or designed.

According to Molina (2016), the calculations suggest that even replacing one third of the animal protein in the average American's diet with plant protein (e.g., beans, grains) can reduce the diet's carbon footprint by half a tone. Exchanging two thirds of the animal protein with plant protein is roughly equivalent to switching from a Toyota Camry to a Prius. Finally, throwing food out not only adds its associated carbon emissions to a person or household's footprint, it adds the emissions of transporting the wasted food to the garbage dump and the emissions of food decomposition, mostly in the form of the highly potent greenhouse gas, methane.

Options to reduce the carbon footprint of humans include Reduce, Reuse, Recycle, Refuse. This can be done by using reusable items such as thermoses for daily coffee or plastic containers for water and other cold beverages rather than disposable ones. If that option isn't available, it is best to properly recycle the disposable items after use. When one household recycles at least half of their household waste, they can save 1.2 tons of carbon dioxide annually. Yet another option for reducing the carbon footprint of humans is to use less air conditioning and heating in the home. By adding insulation to the walls and attic of one's home, and installing weather stripping or caulking around doors and windows one can lower their heating costs more than 25 percent. One can also turn down the heat while sleeping at night or away during the day, and keep temperatures moderate at all times. Setting the thermostat just 2 degrees lower in winter and higher in summer could save about 1 ton of carbon dioxide each year. The carbon handprint movement emphasizes individual forms of carbon offsetting, like using more public transportation or planting trees in deforested regions, to reduce one's carbon footprint and increase their "handprint" (Tukker, 2016).

On the industry level, efforts were put forwarded to reduce industry emission of carbon footprint. The most powerful industrial climate actions are: refrigerant management (90 billion tonnes of CO2e 2017-2050, since refrigerants have thousands of times the warming potential of CO2); land-based wind turbines for electricity (85 billion); reduced food waste (71 billion); and restoring tropical forests by ending use of the land for other purposes (61 billion). They calculate benefits cumulatively to 2050 , rather than annually, because industrial actions have long lead times (Aldridge, 2016).

As stated in Pasquilano (2017), a product, service, or company's carbon footprint can be affected by several factors including, but not limited to energy sources, offsite electricity generation and materials. These factors can also change with location or industry. However, there are some general steps that can be taken to reduce carbon footprint on a larger scale. Carbon Footprints from energy consumption can be reduced through the development of alternative energy projects, such as solar and wind energy, which are renewable resources. Reforestation, the restocking of existing forests or woodlands that have previously been depleted, is an example of Carbon Offsetting, the counteracting of carbon dioxide emissions with an equivalent reduction of 
carbon dioxide in the atmosphere. Carbon offsetting can reduce a company's overall carbon footprint by offering a carbon credit. A life cycle or supply chain carbon footprint study can provide useful data which will help the business to identify specific and critical areas for improvement. By calculating or predicting a process' carbon footprint high emissions area can be identified and steps can be taken to reduce in those areas (Pasquilano, 2017).

\section{Level of Carbon Footprint Status}

In the context of global warming, Schmidt, (2010) defines a carbon footprint as the total amount of greenhouse gas (GHG) emissions for which an organization is responsible. Gases such as carbon dioxide, methane, nitrous oxide and halocarbons are called greenhouse gases (GHGs). They absorb and reradiate the sun's energy. This phenomenon is referred to as the greenhouse effect. This effect keeps the earth $33^{\circ} \mathrm{C}\left(60^{\circ} \mathrm{F}\right)$ warmer than it otherwise would be. However, as concentrations of these GHGs increase in the atmosphere, this warming effect also increases and is referred to as global warming.

Hrung (2013) noted the increasing drive to encourage individuals to understand how their lifestyles and everyday activities contribute to greenhouse gas (GHG) emissions, and how they can reduce their personal 'carbon footprint' (the amount of GHGs emitted by an individual's activities during a specified time period).

Seyfang (2010) emphasized the significance of having carbon literacy for individuals to contribute to reducing carbon footprint. According to him, 'really understanding carbon budgets and how to manage them through behavior change' is 'what we might call "carbon literacy" as an analogue to financial literacy', and that this is a 'previously unidentified and undeveloped competency'.

In the study of Druckman and Jackson (2011), they distinguish carbon capability from carbon literacy by explaining that 'carbon capability implies an understanding of the limits of individual action and where these encounter wider societal institutions and infrastructure, and so prompt the need for collective action and other governance solutions'. Their definition reflects the view that an individual's ability 'to take effective decisions regarding the use and management of carbon' depends on societal infrastructure, government policies and so on, and that carbon capable people will understand this and seek to influence such structures so as to increase their ability to manage their carbon emissions.

Horng, et. al. (2013) have developed a 'low-carbon literacy scale' for use in the tourism industry, and define 'low-carbon literacy' as 'knowledge and understanding of energy conservation and carbon reduction and the incorporation of this literacy into everyday life' $(2013,256)$. Their scale comprises seven constructs including not only knowledge of low- carbon issues but also attitudes and values, action intent, and action strategy. Thus, their definition involves normative assumptions that 'low-carbon literacy' entails holding certain attitudes and values and actively seeking to reduce GHG emissions, rather than simply having the knowledge and skills to do so. The amount of carbon dioxide (CO2) releases with all the activities of a person or other entity (e.g., building, corporation, country, etc.). It is calculation of emissions of greenhouse gases caused directly and indirectly by an organization or company and those that result from fossil-fuel combustion in manufacturing, heating, and transportation, as well as emissions required to produce the electricity associated with goods and services consumed. In addition, the carbon footprint concept also often includes the emissions of other greenhouse gases, such as methane, nitrous oxide, or chlorofluorocarbons (CFCs).

Carbon footprint has become an effective approach for evaluating carbon emission, aiming at tracking down total carbon emission across the life cycle to provide scientific bases for carbon reduction. This paper presents the research progress in carbon footprint analysis based on a comprehensive literature review, summarizing definitions, computational methods and application case histories of carbon footprint. As for computational methods, process analytic method and input-output analysis approach are highlighted. Case histories in this paper report the application of footprint analysis with respect to different scales and industrial sectors/infrastructure departments. Prospects for research trends in the area of carbon footprint are discussed as well (Chen, 2017).

Based on an empirical study in Shanghai, this paper firstly analyses distribution of commuting $\mathrm{CO}_{2}$ emissions among the populations, and finds that almost $80 \%$ of emissions are from top $20 \%$ respondents. To find which factors make those people producing a disproportionately large share of emissions, this paper further analyses the link between individual socio-economic characteristics, transit accessibility, urban built environment and commuting emissions. The results show that among socioeconomic characteristics, male gender, income and car ownership are strongly related with emissions. Rail accessibility doesn't have a significant impact on emissions, while the influence of urban density is weak but significant (Beattie, 2016).

Sun (2016) reported that tourism contributes significantly to global gross domestic product, and is forecast to grow at an annual $4 \%$, thus outpacing many other economic sectors. However, global carbon emissions related to tourism are currently not well quantified. Here, we quantify tourism-related global carbon flows between 160 countries, and their carbon footprints under origin and destination accounting perspectives. We find that, between 2009 and 2013, tourism's global carbon footprint has 
increased from 3.9 to $4.5 \mathrm{GtCO}_{2} \mathrm{e}$, four times more than previously estimated, accounting for about $8 \%$ of global greenhouse gas emissions. Transport, shopping and food are significant contributors. The majority of this footprint is exerted by and in highincome countries. The rapid increase in tourism demand is effectively outstripping the de-carbonization of tourism-related technology. We project that, due to its high carbon intensity and continuing growth, tourism will constitute a growing part of the world's greenhouse gas emissions (Sun, 2016).

In a study by Larry (2010) the issues in estimating the greenhouse gas (GHG) emissions from the tourism industry and related activity in Australia was explored. According to the author, the scope of tourism consists of the economic activities defined as "tourism characteristic" and "tourism connected" as defined in the Australian Tourism Satellite Account (TSA). Two approaches are employed and contrasted - a "production approach" and an "expenditure approach". Depending on the approach, tourism contributes between 3.9\% and 5.3\% of total industry GHG in Australia. The rationale for each approach is explained. The GHG emissions have been estimated for 2003-2004, the latest year for which detailed industry GHG emissions data are available in a form suitable for this type of analysis. Tourism's GHG emissions are compared with other industries in the Australian economy. The policy implications of the results are discussed. It should be possible to adopt a broadly similar method for any destination with TSA - enabling tourism stakeholders to play an informed role in assessing appropriate and effective climate change mitigation strategies for their destination (Larry, 2010).

Hua (2011) examined the carbon footprint across supply chains and thus contributes to the knowledge and practice of green supply chain management. The analytical model uses the long-range Lagrangian and the Eulerian transport methods. Analytical and finite difference methods are used to approximate the three-dimensional infinite footprint model. A simplified numerical example validates and illustrates the proposed approach. The results show that carbon emissions across stages in a supply chain can constitute a significant threat that warrants careful attention in the design phase of supply chains. Greenhouse gas accountings, commonly referred to with the popular term carbon footprints (CFP), are widely used metric of climate change impacts and the main focus of many sustainability policies among companies and authorities. However, environmental sustainability concerns not just climate change but also other environmental sustainability concerns not just climate change but also other environmental problems, like chemical pollution or depletion or natural resources, and the focus on CFP brings the risk of problem shifting when reductions in CFP are obtained at the risk of problem shifting when reductions in CFP are obtained at the expense of increase in other environmental impacts. There is a broad consensus that mankind must reduce carbon emissions to mitigate global warming. It is generally accepted that carbon emission trading is one of the most effective marketbased mechanisms to curb the amount of carbon emissions. This paper investigates how firms manage carbon footprints in inventory management under the carbon emission trading mechanism. We derive the optimal order quantity, and analytically and numerically examine the impacts of carbon trade, carbon price, and carbon cap on order decisions, carbon emissions, and total cost. We make interesting observations from the numerical examples and provide managerial insights from the analytical results (Hua, 2011).

Jung (2018) stated that globally, buildings are responsible for $18 \%$ of greenhouse gas (GHG) emissions and $40 \%$ of energy consumption. The European Union's climate and energy policy framework for 2020 to 2030 requires reducing GHG emissions by $40 \%$, increasing the level of energy savings by $25 \%$, and increasing the share of renewable energy by at least $30 \%$ relative to 1990. The environmental and energy performance criteria for buildings will continually evolve to meet the aforementioned decarbonization goals. Consequently, buildings will have an increased number of variables and alternatives that are to be evaluated for their performance, indicating increased complexity for building designers. The prospect of evaluating multiple building performance criteria necessitates integrated designing and planning tools, such as the use of Building Information Models (BIM), Building Performance Simulations (BPS), and methodologies for comparing and optimizing alternative design options. This dissertation presents new insights on advancing the design criteria for the energy and environmental performance of commercial and residential buildings. Specifically, the four associated journal publications demonstrate how building designers and the Architecture, Engineering, and Construction (AEC) industry can integrate embodied GHG analysis, comprehensive BTM tools in conjunction with BPS analyses, and stochastic assessment of public perceptions to work towards buildings that are more energy-efficient, generate energy on-site, and have a smaller carbon footprint. Through comprehensive literature reviews, this dissertation outlines future research directions for BTM-based, iterative multi-criteria assessment for energy and environmental performance of buildings (Jung, 2018).

Weidmann (2015) emphasized that globalization has led to an increasing geospatial separation of production and consumption, and, as a consequence, to an unprecedented displacement of environmental and social impacts through international trade. A large proportion of total global impacts can be associated with trade, and the trend is rising. Advances in global multi-region input-output models have allowed researchers to draw detailed, international supply-chain connections between harmful production in social and environmental hotspots and affluent consumption in global centers of wealth. The general direction of 
impact displacement is from developed to developing countries-an increase of health impacts in China from air pollution linked to export production for the United States being one prominent example. The relocation of production across countries counteracts national mitigation policies and may negate ostensible achievements in decoupling impacts from economic growth. A comprehensive implementation of the United Nations Sustainable Development Goals therefore requires the inclusion of footprint indicators to avoid loopholes in national sustainability assessments. Carbon footprints and embodied carbon have a strong methodological foundation and provide valuable input into policy formation. The widespread use of carbon footprints using existing knowledge needs to be encouraged and even regulated. At the product level, carbon footprints can empower consumers to shape their own climate friendly behavior and help governments design policies that do not give the wrong incentives. Companies can use carbon footprints to reduce exposure to carbon prices or highlight the positive actions they have taken. Cities and regions can use carbon footprints to implement local policies that help meet overarching national objectives. National carbon footprints can help design equitable and efficient climate agreements that avoid shifting problems to other administrative territories. Further advances can provide strong interdisciplinary links between the physical carbon-cycle, emission drivers, and policy at a variety of scales (Weidmann, 2015).

\section{Carbon Footprint Status in School}

Hua (2011) suggested that in creating a greener school requires educating the community about the importance of reducing carbon emissions and living more environmentally sustainable live. Find a way to communicate and reduce energy use through newsletters or a page on your school's website. Get people involved in taking and meeting the goals to reduce carbon emissions over five years.

Druckmann (2011) supported the claim of Hua (2011) and suggested that school principals should continue to create green schools which are not only environmentally friendly but also generate cost savings in the form of reduced water and energy use. The standard for environmentally friendly schools is "Leadership in Energy and Environmental Design", a framework for building schools that meet certain benchmarks for sustainability, and a certification that more schools are seeking to achieve as they upgrade existing facilities and expand their campuses.

Bellasen (2015) affirmed that principals need to create exercises involving and creating a 'low-carbon' investment challenge among schools. Such skills create a positive atmosphere among students in raising consciousness in terms of carbon footprint. Without a doubt the interdisciplinary nature of the Carbon Management initiative would be known nationwide.

Chen (2017) concluded that our planet's warming climate presents an imminent and catastrophic challenge that will have farreaching economic, social, and political ramifications. As residents of a third world country, we need to intensify our efforts in decreasing our carbon footprint status, we should lessen out contributions in terms of carbon footprint buildup. As globally connected citizens we need to cooperate to the programs of the international scenario by starting it from our own schools and momentarily thinking locally and acting globally. On the other hand, Adanza (2016), persuaded that there is a need to enforce green management in the academic community to be more aware about the issue on carbon footprint. Aside from this, the school may promote and maintain advocacies that could mitigate carbon footprint.

\section{Climate Change Mitigation Awareness}

Climate change occurs when changes in Earth's climate system result in new weather patterns that last for at least a few decades, and maybe for millions of years. The climate system receives nearly all of its energy from the sun, with a relatively tiny amount from earth's interior. The climate system also gives off energy to outer space. The balance of incoming and outgoing energy, and the passage of the energy through the climate system, determines Earth's energy budget. When the incoming energy is greater than the outgoing energy, earth's energy budget is positive and the climate system is warming. If more energy goes out, the energy budget is negative and earth experiences cooling.

As this energy moves through Earth's climate system, it creates Earth's weather and long-term averages of weather are called "climate". Changes in the long-term average are called "climate change". Such changes can be the result of "internal variability", when natural processes inherent to the various parts of the climate system alter Earth's energy budget. Examples include cyclical ocean patterns such as the well-known El Niño-Southern Oscillation and less familiar Pacific decadal oscillation and Atlantic multi-decadal oscillation. Climate change can also result from "external forcing", when events outside of the climate system's five parts nonetheless produce changes within the system. Examples include changes in solar output and volcanism.

Human activities can also change earth's climate, and are presently driving climate change through global warming. There is no general agreement in scientific, media or policy documents as to the precise term to be used to refer to anthropogenic forced change; either "global warming" or "climate change" may be used. The first describes the average effect on a global scale, whilst the second describes how different geographical regions are affected differently (Solomon, 2010). 
The field of climatology incorporates many disparate fields of research. For ancient periods of climate change, researchers rely on evidence preserved in climate proxies, such as ice cores, ancient tree rings, geologic records of changes in sea level, and glacial geology. Physical evidence of current climate change covers many independent lines of evidence, a few of which are temperature records, the disappearance of ice, and extreme weather events.

The most general definition of climate change is a change in the statistical properties (principally its mean and spread) of the climate system when considered over long periods of time, regardless of cause. Accordingly, fluctuations over periods shorter than a few decades, such as El Niño, do not represent climate change.

The term "climate change" is often used to refer specifically to anthropogenic climate change (also known as global warming). Anthropogenic climate change is caused by human activity, as opposed to changes in climate that may have resulted as part of Earth's natural processes. In this sense, especially in the context of environmental policy, the term climate change has become synonymous with anthropogenic global warming. Within scientific journals, global warming refers to surface temperature increases while climate change includes global warming and everything else that increasing greenhouse gas levels affect (Hsiung, 2010).

A related term, "climatic change", was proposed by the World Meteorological Organization (WMO) in 1966 to encompass all forms of climatic variability on time-scales longer than 10 years, but regardless of cause. During the 1970s, the term climate change replaced climatic change to focus on anthropogenic causes, as it became clear that human activities had a potential to drastically alter the climate. Climate change was incorporated in the title of the Intergovernmental Panel on Climate Change (IPCC) and the UN Framework Convention on Climate Change (UNFCCC). Climate change is now used as both a technical description of the process, as well as a noun used to describe the problem (Vallis, 2010).

\section{Eco-School Toolkit}

Eco-schools raise environmental awareness. The skills and knowledge gleaned from the Eco-School programme have a life-long positive impact on the lives of young people, their families, school, staff, and local authorities to raise. Eco-School is a growing phenomenon which encourages young people to engage in their environment by allowing them the opportunity to actively protect it. It starts in the classrooms; it expands to the schools; and, eventually fosters change in the community at large. Through this programme, young people experience a sense of achievement at being able to have a say in the environmental management policies of their schools, ultimately steering them towards certification and the prestige which comes with being awarded a Green Flag. The Eco-Schools programme is an ideal way for schools to embark on a meaningful path towards improving the environment in both the school and the local community while at the same time having a life-long positive impact on the lives of young people, their families, school staff and local authorities

ECO-UNESCO undertook a Pilot project on Sustainable Development in Primary and Secondary School which explored curricula links to COMHAR's Principles of Sustainable Development and a whole schools approach to ESD. One outcome is the development of a Primary Schools Toolkit which helps teachers integrate ESD into their everyday classroom activities by providing them with the necessary materials to run various class sessions and outlines ideas for practical projects. It also provides information for a whole schools' approach, offering information on other programmes. Focus on educational and learning dimensions. Active learning, learner-centred approach, Curricular links, Practical Project element, and Reflective learning.

Green School is an international programme that focuses on a 'whole schools approach' to environmental awareness. It promotes responsible behaviour among school children and the wider community towards the environment. It offers a welldefined, controllable way for schools to take environmental issues from the curriculum and apply them to the day-to-day running of the school. Over 2600 schools (primary, secondary and special) are registered and participating in the programme run by an Taisce. The programme is particularly successful at primary level where timetabling, class structure (i.e. one teacher to one class) and the size of schools makes it easier to achieve a whole-schools approach to ESD. A key to the success of the programme is the partnership between An Taisce and all of the Local Authorities who provide funding and also support through their Environmental Awareness Officers. The programme is part-funded by the Department of Environment. Focus on educational and learning dimensions endeavours to make environmental awareness an intrinsic part of the school ethos; participation is encouraged from not just students, teachers, and parents but also from the Local Authority, the media, and local business. The programme is evaluated. The Green Flag award requires renewal every 2 years, thus promoting continued reduction of the school's environmental impact (Smith, 2016.)

The Eco-Schools programme is an international programme of the Foundation for Environmental Education (FEE) that was developed to support environmental learning in the classroom. The programme is active in 67 countries around the world and 
has been implemented in South Africa since 2003 by WESSA. The programme is aimed at creating awareness and action around environmental sustainability in schools and their surrounding communities as well as supporting Education for Sustainable Development in the national curriculum. With over $50 \%$ of the content in some CAPS subjects being environmental in nature, Eco-Schools makes a positive contribution towards improving education in South Africa. The programme accredits schools that make a commitment to continuously improve their school's environmental performance. The Eco-Schools programme is operational in both supported and unsupported schools. Schools may register any time throughout the year, and submit evidence for an award within 8 to 12 months of registration with the Provincial Awards Ceremonies taking place in March annually.

\section{Methodology}

The main purpose of the study was to determine the levels of carbon footprint status, climate change mitigation awareness, and education for sustainable development perceptions of 210 out of 420 secondary school principals in the Island of Panay for school year 2019-2020. The researcher employed mixed method research design: quantitative and qualitative approach.

Aside from 210 sample participants who were randomly selected for the survey, two sessions of focus group discussions were conducted to the Philippine - Open Government Partnership (P-OGP), National Executive Coordinating Council (NECC) and international philanthropists.

The quantitative data in this study were gathered using researcher-made questionnaires: Carbon Footprint Status Questionnaire (CFSQ,) Climate Change Mitigation Awareness Questionnaire (CCMAQ), and Education for Sustainable Development Perceptions Questionnaire (ESDPQ); while the qualitative data were collected through a Focus Group Discussion (FGD) Guide Questions.

The Eco-School Toolkit was adopted from the 4Ds Training Cycle Map Process by Samuel Phil (2010). The process followed four steps: (1) Define, where the researcher conducted an environmental scanning regarding the necessity and practicability of the Eco-School Toolkit, (2) Discover, where the study was conducted in Panay Island to know what activities and innovations should be included in the Eco-School Toolkit, (3) Develop, where the assessed levels of carbon footprint status, climate change mitigation awareness, and education for sustainable development perceptions were tallied, analyzed, and interpreted as bases for the development of the Eco-School Toolkit, and (4) Demonstrate, where the Eco-School Toolkit was formally introduced to the school principals of Panay Island.

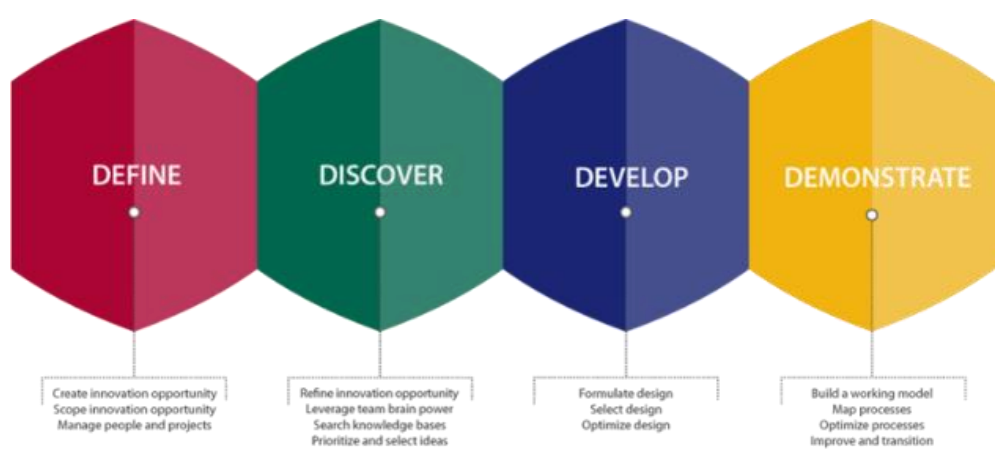

Figure 1. 4Ds Training Cycle Map Process by Samuel Phil (2010)

The data was statistically interpreted through frequency counts, percentage, mean, standard deviation, Analysis of Variance, Pearson correlation coefficient at 0.05 level of significance.

\section{Results and Discussion}

\section{Level of Carbon Footprints of Principals in Panay Island}

The result in Table 1 indicated that carbon footprint status of the principals in the Island of Panay was "High" with $\bar{x}=3.61, s d=$ 0.84. Generally, the results in Table 1 revealed that the principals have "high" level of carbon footprint status. Consequently, it is alarming of great extent. They may have carbon-based practices which needs to be addressed. Principals may have exceeded beyond the normal or standard carbon footprint status. They may be oblivious about the idea and incognizant in terms of the impacts in their own lifestyles vis-à-vis their anthropogenic effects in the environment as school managers.

There are several factors that resulted into their low adherence of the carbon footprint like carbon friendly habits that need to be upgraded such as meatless Monday diet, eating vegetarian food, patronizing organic products, utilizing plastic bottles as 
containers, repetition of old clothes. Likewise, carbon friendly attitudes to be refined like using of eco-bags in groceries, unplugging of appliances when not in use, shopping at ukay-ukay, compost pit for waste management, utilizing technology to reduce workloads. Similarly, carbon friendly practices that requires amelioration like recycling in the offices, using of CFC friendly air conditioning, using of drinking glass in brushing, old light bulbs replacement and using public transportation, carbon friendly cultures that require improvement namely tree planting, walking-jogging-exercising, proper food storage, spraying aerosols and temperature monitoring of refrigerators. All these factors significantly contributed to the "high" level of carbon footprint status.

From a practical perspective, the current findings have implications for carbon reduction program. It is an initiative to be integrated in the school-based management motivating the schools to assess carbon friendly habits, revisit carbon friendly attitude, enhance carbon friendly practices and embrace carbon friendly culture. This will accelerate the consciousness level of the school. This may be done with a competent carbon footprint coordinator appointed by the school principal. Additionally, the carbon reduction program may be integrated in the School Improvement Plan with corresponding budget taken from the Maintenance and other Operating Expenses (MOOE) allocations for government schools.

Further, the results implied that the principals' high level of carbon footprint status could be easily translated to the school that it is productive. Community involvement, school collaboration and sustainable planning can also help in the drive to reduce carbon. On the other hand, the use of non- (chlorofluorocarbon) CFC friendly air conditioning in the offices of the principals and non-energy efficient appliances may contribute to the "high" level of carbon footprint status.

The results above attested by a discussant as "Carbon dioxide is so high because of air conditioning in the offices, thus principals need to use "energy efficient appliances". It's not ok for carbon footprint to be "high" since climate change is not natural - the impact causes global warming. As of now, United Nations by 2030 is targeting to lower the temperature around the globe - by lowering ones carbon footprint. The goal here is that it should be decreased - and that is urgent".

Moreover, school principals are already used to travel by personal cars during business transactions in the different division offices in Panay Island like management committee meetings (MANCOM), submission of paper documents, liquidation narratives of the MOOE and urgent reports with official deadlines.

One of the discussants agreed with the implications and insights regarding this finding. Principals are using cars normally. In the Division of Antique itself cars are abundant among principals since nowadays the demand of work is so high that we need to comply all the requirements from the DepEd ranging from reports, to analyses and liquidation - our contact with DepEd is needed thus we need to travel by cars since documents to be valid for passing need to have "RECEIVED" stamps, and I just realized now that - when you frequently use cars on a day to day basis, you are consuming more carbon dioxide, thus your carbon footprint becomes "high" as a matter of fact it should be "low".

The results of the study conform based on the research of Bellasen (2015) that school principals are encouraged to create exercises involving and creating a 'low-carbon' investment challenge among schools. Such skills create a positive atmosphere among students in raising consciousness in terms of carbon footprint. Without a doubt the interdisciplinary nature of the Carbon Management initiative would be known nationwide.

Furthermore, it complied with the study of Chen (2017) that as residents of a third world country, we need to intensify our efforts in decreasing our carbon footprint status, we should lessen out contributions in terms of carbon footprint buildup. As globally connected citizens we need to cooperate to the programs of the international scenario by starting it from our own schools and momentarily thinking locally and acting globally. Additionally, it abides with the concept of Druckmann (2011) that school principals should continue to create green schools which are not only environmentally friendly but also generate cost savings in the form of reduced water and energy use.

Lastly, it follows the idea of Hua (2011) that creating a greener school requires educating the community about the importance of reducing carbon emissions and living more environmentally sustainable lives. Get people involved in taking and meeting the goals to reduce carbon emissions over five years.

The data also showed that in terms of age ranging from 36-45 years old had the highest $\bar{x}=3.90, s d=0.80$ followed by below 25 years old $(\bar{x}=3.62, s d=1.00)$, 46-55 years old $(\bar{x}=3.55$, $s d=0.85)$, above 56 years old $(\bar{x}=3.52, s d=0.83)$ and lastly $26-35$ years old $(\bar{x}=3.51, s d=0.86)$. In terms of age, the principals across age groups had "High" levels of carbon footprint status. This means that regardless of the age group, school principals have active carbon dominated lifestyle. This also implies that the school principals concern on reducing carbon is of least priority since they are conditioned to attend meetings, travel with their own cars, consume maximum energy on a day to day basis and overloaded by paper works with corresponding deadlines. 
In the interviews conducted, the principals shared that carbon footprint status is something new to them. The novelty of the idea was perceived superficially. They were unfamiliar about the concept and required enlightenment on how to reduce carbon footprint status to embrace an environment-friendly and pro-sustainability attitude in thoughts, actions and words. This could be attested by the insight a principal, "As principal I never had an idea of what carbon footprint is all about, only just now that all of us are called to lower down our status in carbon footprint. Which means each principal of different age, sexual orientation, and geographical location contribute to the rising of carbon footprint status. This manuscript is a wake up call for me to be more responsible personally in my lifestyle as a leader since so much is expected from me".

Ages 36-45 revealed as the highest in terms of mean score of 3.90 and standard deviation of 0.80 . School principals at this age bracket are hungry for promotion and recognitions thus they strive hard to achieve their dreams. They work hard thus they consume too much carbon which resulted to their "high" level of carbon footprint. They are working longer and retiring later, then the "emissions-reducing effect" may not be realized during their lifespan. "I usually agree that ages 36-45 obtained the highest mean in terms of carbon footprint status since during my prime days I usually hunger for "self fulfilling prophecy". It was the stage of my life that I needed to be noticed and praised. I call that, the "pivotal point of success", but those days were also the times that I consumed carbon too much. It was really a self realization that I just want to share with the group". While another principal attested that "That was the time where travelling became a "want" than a "need". Times where I travelled everyday and really tried to impressed my friends and relatives that one of these days I'm gonna be somebody without realizing I also did something wrong with my carbon footprint status. I want new clothes everyday, beef stakes for dinner, I failed to exercise but used my cars driving from South Luzon Expressways to Baguio City. It was really days of exploration and destruction at the same time.".

The result validated the research of Jones (2011) that ages 36-45 should be more sensitive to environmental issues since they grew up with environmental lectures and symposia, however; they need to be reinforced and recalibrated for an authentic environmental commitment and dedication in healing nature.

The findings run counter with the research of Chen (2017). It is the millennial age 25 below comprised the most ethnically diverse generation. They are more open-minded and raised in a networked world. They are optimistic about sustainability and aggressive enough to lower down carbon footprint and embrace environmental resiliency.

In terms of sexual orientation, it had "High" level of Carbon Footprint Status homosexuals had the highest $\bar{x}=3.88, s d=0.94$, followed by heterosexual which were $\bar{x}=3.58, s d=0.83$ and bisexual $(\bar{x}=3.50, s d=0.77)$. With respect to sexual orientation the principals had "High" level of carbon footprint status. This means that whether they are homosexual, heterosexual and bisexual they are encouraged to have carbon friendly habitudes. Practicing activities that lead to reducing carbon footprint status will make them environmentally resilient principals.

This can be validated by the statement of a principal "They must admit it among themselves but sad to say it was not part of their priorities as principals. I think since it was there first time to answer the questionnaires then your data will be considered as preliminary analysis. They need to re-establish a culture of lowering the carbon footprint among themselves as principals and seriously apply it among themselves regardless of age, sexual orientation and geographical location".

For the geographical location, both urban and rural had "High" levels of carbon footprint status with $\bar{x}=3.64, s d=0.82$ and $\bar{x}=$ $3.55, s d=0.91$, respectively. In terms of geographical location of principals, they also have "High" level of carbon footprint status. This means that the principals stationed in rural and urban areas contributed to the increase of carbon footprint status. Regardless of station, they are driving cars daily, eating too much meat, minimal recycling practices, uses plastics instead of ecobags and consume too much energy in the offices. According to a principal "I was never aware of my carbon footprint but I was educated before by my science professors in the University Philippines Diliman to lower down my personal consumption of carbon for the planet earth. This study is beneficial among all Filipinos living in today's world to take action on how to decrease carbon footprint, but of course they need to assess first their carbon footprint status utilizing this researcher-made questionnaire".

This run counter with the research of Weidmann (2015) that carbon footprints are highly concentrated in affluent cities. "Institutions also need to be "leading by example". We need to use our positions to showcase climate leadership, and amplify positive individual actions across society.

The RPMS-PPST Rating shows that the level of carbon footprint status was "High" in outstanding rating with a $\bar{x}=3.73$, sd $=$ 0.87 , and followed by very satisfactory $(\bar{x}=3.60, s d=0.80)$. The rating satisfactory had "Moderate" level with $\bar{x}=2.75, s d=$ 0.98 . 
Meanwhile, the level of carbon footprint status with respect to the RPMS-PPST Ratings of principals, those with Outstanding and Very Satisfactory Ratings had "High" levels of carbon footprint status while those with Satisfactory RPMS-PPST Rating had "Moderate" (Mean = 2.87; SD = 1.01) level of carbon footprint status.

The findings are attributable to the maximum energy consumed by principals. Top performing principals with outstanding and very satisfactory RPMS-PPST ratings use cars to travel to the different division offices just to submit paper works, they consume too much paper in doing the errands, they eat too much meat as protein sources and they usually look good by wearing new clothes every day and in meetings they receive the usual attention because of their clothes.

In contrast with principals who have "satisfactory" ratings they perform activities with minimalism. They let the PUV (Public Utility Vehicle) act as "courier" in passing the needed reports in the divisions office, they recycle paper in the office, they eat vegetarian food regularly, they subject to paperless system since they don't aspire for too much modes of verifications (MOVs) just to receive an "outstanding" or very satisfactory RPMS-PPST ratings (lesser paper, lesser carbon footprint philosophy) and most importantly they are more economical in terms of clothing since they wear old clothes due to the fact that they are not the cream of the crops - they have less exposures in terms of recognitions thus they seat at the back portions of the halls during meetings and conferences.

This was attested by principal that "Top performing leaders consume too much energy, let them strategize effective activities that are environment friendly. They are using gasoline in going to the different places, thus they need to do carbon off setting. I always believe that they need to offset. Just like in the national level, senators are using too much carbon footprint since they always travel by plane". While, "In terms of simplicity I think the balancing act is necessary. Just like my cellphone, its low tech, the more expensive the cellphone, the more carbon footprint you use, look at the result, principals which have simple ratings have moderate status in terms of carbon footprint". Further, "It's true, simplicity and going back to the basics will always be the key. As you notice hedonistic kind of living will lead to increase carbon footprint. Lower footprint but high performance. "Pareto Effect" should be incorporated to any professions in the world". It was further agreed that "Achievement-orienteers is the theme of the evaluation processes and sad to say competition instead of cooperation is the orientation thus it is never integrally managed. Everybody wanted to be on the top. School heads OPCRF? it's the CID of the Divisions Office who checks them. We cant have outstanding ratings without MOVs. If we have 5 boxesof MOV then better. In doing all these "extravagants" we are increasing carbon footprints and these need to be given attention. Thus, being "Makakalikasan" should be part of RPMS-PPST. There's no weight for environmental advocacies, just plain intellectual development".

The study keeps to the insight of Tukker (2016) that many factors affect the carbon footprint of every employed citizen but the impact of our actions are commensurate of our footprint. The more hyper a person is the more carbon footprint he has, the more relaxed the person is the lesser the carboon footprint will be. Those of us who want to step forward on climate need to know how our actions can have the greatest possible impact.

The findings holds to the idea of Sun (2016) that one way to decarbonized our professional practices is by being more inclusive, inventive and useful. Virtual conferencing may help reduce carbon footprint status instead of making our principals travel to different places just to attend a meeting - thus they consume too much carbon. Experimenting with fresh and exciting conference formats and imagining ways to increase opportunities for meaningful and sustainable sociability will help save the environment. BY making our works more efficient and effective not just ratings and performance evaluation- based working.

Further, the result implied that the adherence to carbon footprint emission does not necessarily vary across ages, sexual orientation and geographical location. This calls for an inclusive program for carbon footprint reduction which will increase the level of knowledge of the principals about the concept of carbon footprint, including the measures to decrease them. 
Table 1. Level of carbon footprint status of principals.

\begin{tabular}{lccl}
\hline & $\bar{x}$ & $s d$ & Description \\
\hline \hline Age & & & \\
$\quad$ Above 56 yrs old & 3.52 & 0.83 & High \\
$46-55$ yrs old & 3.55 & 0.85 & High \\
$\quad 36-45$ yrs old & 3.90 & 0.80 & High \\
$\quad 26-35$ yrs old & 3.51 & 0.86 & High \\
$\quad$ Below 25 yrs old & 3.62 & 1.00 & High \\
$\quad$ Sexual Orientation & & & \\
$\quad$ Heterosexual & 3.58 & 0.83 & High \\
$\quad$ Homosexual & 3.88 & 0.94 & High \\
$\quad$ Bisexual & 3.50 & 0.77 & High \\
Geographical Location & & & \\
$\quad$ Urban & 3.55 & 0.91 & High \\
$\quad$ Rural & 3.64 & 0.82 & High \\
$\quad$ RPMS-PPST Rating & & & \\
$\quad$ Outstanding & 3.73 & 0.87 & High \\
$\quad$ Very Satisfactory & 3.60 & 0.80 & High \\
$\quad$ Satisfactory & 2.75 & 0.98 & Moderate \\
Total & $\mathbf{3 . 6 1}$ & $\mathbf{0 . 8 4}$ & High \\
\hline \hline
\end{tabular}

Legend:
\begin{tabular}{|c|l|}
\hline Scale & \multicolumn{1}{c|}{ Description } \\
\hline $4.21-5.00$ & Extremely high \\
\hline $3.41-4.20$ & High \\
\hline $2.61-3.40$ & Moderate \\
\hline $1.81-2.60$ & Low \\
\hline $1.00-1.80$ & Extremely low \\
\hline
\end{tabular}

Level of Climate Change Mitigation Awareness of the Principals

The level of climate change mitigation awareness of the principals is reflected in Table 4. It is shown that the principals have "High" level of climate change mitigation awareness with $\bar{x}=3.58, s d=0.93$. The principals have "high" level of climate change mitigation awareness which alludes that principals may be well acquainted in extenuating consciousness on responding climate change mitigation in schools. They may have relatively intent-oriented pro environmental behaviors that contributed to its "high" level and may behave in an ecologically responsible manner emphasizing actions with relatively ecological benefits.

The percipience of principals on this matter and resulted into "high" level are attributable to pro climate change routines like living pro-earth lifestyle, using unleaded gasoline, online shopping, water conservation, air drying of clothes instead of machine, pro climate change mitigation stance similar to spreading of awareness, buying of energy friendly appliances, using of LED energy lightning, using of "bayong", lunchbox instead of styrofoam for lunch, pro climate change mitigation insights same in fashion with, involving teachers in eco-friendly advocacies, practicing earth-hour, turning off lights when not in use, avoiding products with too much packaging and replacing filters regularly in the air conditioning, and pro-climate change mitigation beliefs like promoting green schools in the community, recycling of papers, plastics, metals and cooling devices and food wastage.

Climate change mitigation awareness is currently integrated in the four core values of Department of Education : Maka-Tao, Maka-Diyos, Maka-Bansa and Maka-Kalikasan. The government has responded actively to climate change; creating relevant legislation and new institutional mandates. Currently, six laws explicitly address climate change and a recently approved senate bill will create a Climate Change Commission to ensure coordination across a variety of relevant national agencies. Thus, school principals of government affiliations are commanded to religiously live a "high" or "extremely high" levels of climate change mitigation awareness.

From a practical perspective, the current findings have implications for school principals maybe to have climate change mitigation awareness symposium. It is an innovation to maintain and sustain pro-climate change routines, stance, insights and beliefs. Additionally, the climate change mitigation awareness symposium may be integrated in the School Improvement Plan with corresponding budget taken from the Maintenance and other Operating Expenses (MOOE) allocations for government schools.

According to principal-participant, "Awareness level should have the goal of making everything "extremely high" each of them should be motivated since "motivation" is your driving force to increase your mitigation awareness of climate change, knowing they are principals the "prime mover" of change. The problem is that awareness should be coupled with actions for us to be convinced that they are climate change mitigation advocates. We also have spiritual resiliency in doing advocacy on climate change. This is not just about your levels, but you are resilient enough and the approach should be wholistic and inclusive". Other principal 
attested that "This is a very good study for principals to be climate change inclined individual. Remember, they are the heads of the school. They man the whole community and innovation starts from there hands, therefore an "extremely high" level of climate change mitigation awareness, might as well lead to school effectiveness and productivity. "High" is technically alarming. We will not wait anymore, we have to make it "Extremely High" there are reasons to do something. Let the toolkit be published and I will be the first one to implement it in my school".

The result matches up with the content from IPCC (2017) that schools have no exemptions in climate change education. They should strive to increase their awareness on this matter. With heat and power being emitted from classrooms, students and staff travelling to and from school, waste management, and the supply chain activities of companies providing goods and services, schools are contributors to this issue whether they like it or not.

Consequently, it meets with Ekpekin's (2015) research that a school is an academic institution built for the purpose of providing learning spaces and environments for the teaching of students or pupils under the instructions and supervision of the teachers. As principals, schools should maintain several ways and techniques by which climate change mitigation awareness can be greatly increased when certain steps are taken and especially when cogent actions and important support are received from the governments at all levels.

Similarly, it fulfills the idea of Bondoc (2016) that the role of schools in the Philippines must be expressed in its key mission of producing and disseminating knowledge and of engaging the community in the learning process. In the issue of climate change, schools must impact the individuals' general awareness of the issue while at the same time, to determine how enabled they are to develop the necessary solutions and innovations to overcome climate change. Education provides the skills people need to thrive in the new sustainable economy, working in areas such as renewable energy, smart agriculture, forest rehabilitation, the design of resource-efficient cities and sound management of healthy ecosystems.

Be in accordance with, Al-Yousuf (2016) that empowering the schools of today and address climate change impacts is an educational priority. Enhancing their level of awareness is necessary because they are the future citizens and decision makers that must live with the impacts of climate change. They are also the future agents of action who would implement climate change solutions. Therefore, the active participation of schools could provide an intergenerational viewpoint of present and future citizens and school principals have the authorities' to response to climate change, actively empowering young people to prepare them for future climate change adaptive and mitigative actions.

In terms of age, those in age groups highest was age 36-45 with a mean of $\bar{x}=3.86, s d=0.90$, followed by below 25 years old $(\bar{x}=3.78, s d=1.24)$, above 56 years old $(\bar{x}=3.63, s d=0.90), 26-35$ yrs old $(\bar{x}=3.54, s d=0.71)$ and lastly $46-55 \mathrm{yrs}$ old $(\bar{x}=$ $3.38, s d=0.94)$ with "moderate" level of climate change mitigation awareness.

In age group 46 - 55 years old had "Moderate" level of climate change mitigation awareness which means that principals on this age bracket are focusing on their retirement benefits and it requires maximum document preparation. Building strong relationships among teachers instead of conceptualizing eco-friendly advocacies, reflecting on the teacher's achievements instead of green school education, spiritual formation recollections instead of pro-earth lifestyle and accounting their loans among private banks and government firms before retirement instead of spreading awareness on climate change mitigation are their top priorities.

This implied that school leaders from ages 46-55 may be encouraged to intensify environmental protection projects before retirement in the public service for them to maybe cultivate a sense of "environmental legacy" for climate change. According to principal-participant, For me, ages 46-55 is the "interphase" stage of life. This is the time that you reflect on the good things and bad things that happen in your life as school principles. It may be true that climate change mitigation awareness is no longer a priority since after all the unselfish service that you rendered to the school for many years, its about time to think of your self as a government worker. Sometimes being so selfish leads us to a point that we neglect to be selfless for mother earth.

The data conform the study of Hag (2013) that two age-related attributes that could potentially support taking an active stance on climate change are wisdom and environmental advocacy. Wisdom has been defined as the application of successful intelligence and creativity as mediated by values toward the achievement of a common good through a balance among intrapersonal, interpersonal, and extra personal interests while environmental advocacies are healing nature physically and environmentally in thoughts and actions through active involvement despite of old-age related mentality. 
With respect to sexual orientation, the level of climate change mitigation awareness of bisexuals was "Moderate" $(\bar{x}=3.04, s d=$ $0.56)$; while that of heterosexuals $(\bar{x}=3.58, s d=0.09)$ and homosexuals $(\bar{x}=3.76, s d=1.01)$ were "High". Pathologically speaking bisexuals are neurotic or mentally unstable individuals because they are in conflict trying to decide whether they are homosexuals or heterosexuals and have difficulty in decision making. They are confused individuals with unstable decisive personalities rather than an authentic sexual orientation equally valid as heterosexuality or homosexuality.

It can be implied that in terms of climate change mitigation awareness bisexual principals focus more on discovering their true identity whether they will settle on matrimony or solitary life. Environmental literacy is the second priority. As they perform their noble mission as school principals issues on personal formation and emotional stability validated by their true identities are their focus as school managers.

This observation negated the personal concepts of principal-participants believing that homosexuals are more irresponsible than bisexuals in terms of climate change mitigation awareness in the Focus Group Discussion. One principal attested that "Orientation of the person affects Climate Change Mitigation - the more they spray the more they contribute to the destruction of the planet earth. We do have saloons who are using aerosols spray for hair enhancement- they should undergo orientation and seminar on how to counteract this habit of aerosols spraying in the hairs. Since homosexuals in the parlors contribute in the increasing level of carbon footprint, they should be properly oriented on responsible beauty enhancement practices that stops using of aerosols". Another principal added that, "Homosexuals interest in life were concentrated more on their love life once they are in the state of relationship, environmental awareness will never be a priority. They will do more to have money thus they do sometimes overtime in the parlors just to have something for their lover. Thus, spraying of aerosols mean more customers and may lead to more income for their lovers".

The result complied with the research of Wong (2016) regarding bisexuals "moderate" rating in climate change mitigation awareness because according to him, mainstreaming bisexuals in climate change policies and programmes help ensure the integration of gender issues, needs and contributions across the planning and execution cycle of climate change policies and projects. Bisexuals are "undecided" orientation thus their perceptions on environmental issues always connote ambivalence.

Tatiana (2015) abided by the result since climate change is not gender neutral it affects women and men differently. There are complex and dynamic links between gender and climate change in terms of vulnerability to the adverse impacts of climate change as well as in terms of response to climate change, both in terms of mitigating the levels of greenhouse gases (GHGs) and adapting to those impacts of climate change that cannot be avoided. Members of LGBTQ should understand that vulnerability, exposure, sensitivity and adaptive capacity are the reasons for understanding climate change mitigation.

Broody (2014) observed in his research that improved understanding of women's and men's knowledge, roles and abilities will provide a solid basis for policy and programmes developed to address and combat the differentiated impacts of climate change on different gender groups. There is a need, therefore, to conduct an in-depth and evidence-based analysis of women's and men's roles in sectors impacted by, and their strategies for coping with, climate change.

The geographical orientation of the principals also indicates that both coming from the rural $(\bar{x}=3.59, s d=0.94)$ and urban $(\bar{x}=3.55, s d=0.90)$ areas had "High" levels of climate change mitigation awareness. The geographical location of the principals also indicated that both coming from the rural and urban areas have "High" levels of climate change mitigation awareness means that principals stationed both in rural and urban areas are active and resilient in supporting the climate change mitigation efforts of the government as being employed in the respective government schools of Panay.

The result was attested by the statement of a principal, "Climate change mitigation awareness are everybody's concern whether a principal works in the rural or urban areas. Their lifestyle is almost similar since both of them have general job descriptions and mandate from the central office. They might live differently in terms of residences and stations that they served government schools and utilizing MOOE released by DepEd - a government agency.

Dube (2013) followed this learning in a different lens because according to him rural people are engaging in a plethora of activities as resilience mechanisms to withstand the effects posed by climate change. However, some of their income-generating activities are reliant on agricultural and forest products, which are susceptible to climate change and variability. Adaptive capacity among rural people is typically limited by poverty, poor public and environmental health, weak institutions, lack of infrastructure and services, marginalization from decision-making processes and planning procedures, gender inequality, lack of education and information, natural disasters, environmental degradation, reliance on rain-fed agriculture and climate-sensitive resources, and insecure tenure. 
Folke (2016) keeps to emphasizing his "resilience theory" which provided useful lens for examining the challenges faced by rural communities in mitigating the effects of climate change. The strengths over problems concentrating the developing person and the social and physical environments with successful adaptation despite challenging or threatening circumstances.

Further, the principals who have Outstanding $(\bar{x}=3.59, s d=0.96)$ and Very Satisfactory $(\bar{x}=3.58, s d=0.90)$ RPMS-PPST Rating have "High" levels of climate change mitigation awareness; while those who have Satisfactory $(\bar{x}=3.35$, sd $=1.07$ rating had "Moderate" level of climate change mitigation awareness.

This can be implied by the reality of the matter that principals who belong to satisfactory rating in the RPMS-PPST don't need to organize eco-friendly advocacies as part of school innovation, they don't need to have green school education as part of school initiatives, living a pro-earth lifestyle is not their primary concern anymore and spreading awareness on climate change as part of best practices of the school are not part of their plans since they are already satisfied with "satisfactory" rating in the RPMS-PPST rating. For one to be "outstanding" or "satisfactory" one has to comply all the standards set by Department of Education (DepEd) on being "maka-kalikasan" - highlighting climate change mitigation programs.

The findings were attested by a principal stating that "YES. In ASU we encouraged ourselves to do tree planting activity. The forestry department are engaged holistically into it. We also have solid waste management, that's why ASU won as Greenest University. The Regional Center for Northern Panay Climate Change is located inside the university as well. We do free seminars and trainings to prospective trainers on climate change mitigation awareness. Thus, in accreditations we always have positive results, since we do practice what we preach thus documentation is necessary. Further, "PAVIA NHS is putting up a plant nursery. We identified heat resistant plants like succulent plants example Oregano, that is resilient for drought, seedlings of jackfruit the leaves of jackfruits have bigger stomata they absorb bigger amount of carbon dioxide. One of that is increasing moisture of building and make the buildings more prone to destruction. As the temperature rises, water is needed, these innovations are part of RPMSPPST Ratings.

The finding conforms the study of Smith (2016) that employees with average ratings are already demotivated to excel in their specific functions since recognitions are due to employees with excellent and impressive performance evaluation ratings.

Fillardo (2016) holds to the awareness on climate change mitigation as the concern of all components of the school system thus, ratings will never affect the love and care of each employees to take care of the planet earth.

Table 2. Level of climate change mitigation awareness of principals.

\begin{tabular}{llll}
\hline & $\bar{x}$ & $s d$ & Description \\
\hline \hline Age & & & \\
$\quad$ Above 56 yrs old & 3.63 & 0.90 & High \\
46-55 yrs old & 3.38 & 0.94 & Moderate \\
36-45 yrs old & 3.86 & 0.90 & High \\
$26-35$ yrs old & 3.54 & 0.71 & High \\
Below 25 yrs old & 3.78 & 1.24 & High \\
Sexual Orientation & & & \\
$\quad$ Heterosexual & 3.58 & 0.92 & High \\
$\quad$ Homosexual & 3.76 & 1.01 & High \\
$\quad$ Bisexual & 3.04 & 0.56 & Moderate \\
Geographical Location & & & \\
$\quad$ Urban & 3.55 & 0.90 & High \\
$\quad$ Rural & 3.59 & 0.94 & High \\
RPMS-PPST Rating & & & \\
$\quad$ Outstanding & 3.59 & 0.96 & High \\
$\quad$ Very Satisfactory & 3.58 & 0.90 & High \\
$\quad$ Satisfactory & 3.34 & 1.07 & Moderate \\
Total & $\mathbf{3 . 5 8}$ & $\mathbf{0 . 9 3}$ & High \\
\hline \hline
\end{tabular}

Legend:
\begin{tabular}{|c|l|}
\hline Scale & \multicolumn{1}{c|}{ Description } \\
\hline $4.21-5.00$ & Extremely high \\
\hline $3.41-4.20$ & High \\
\hline $2.61-3.40$ & Moderate \\
\hline $1.81-2.60$ & Low \\
\hline $1.00-1.80$ & Extremely low \\
\hline
\end{tabular}

Level of Education for Sustainable Development Perceptions of Principals

Table 3 displayed the education for sustainable development perceptions of principals. The principals have "High" level of education for sustainable development perceptions $(\bar{x}=3.58, s d=0.81)$ which means they complied with DepEd mandate on SBM wash in schools via clean water and sanitation, active in promoting highly sustainable school through brigade eskwela, participate in school activities that promote good health and well being like yearly medical check up for government employees 
and intensify gulayan sa paaralan for a green school community.

Additionally, in view of the fact that they may have high technical knowledge and ecological consciousness on how to sustain developmental-cum-educational programs. They may also have impact-oriented pro-environmental attributes with eco-centric mindset instead of anthropocentric preconceptions.

The result clearly showed that school principals understand the interrelationship between the three components because knowledge from the natural sciences, social sciences and humanities are needed to understand the principles of sustainable development. The principals may even strive to make the level "extremely high" due to the fact that education for sustainable development also promote sustainable living by addressing the learning skills, perspectives and values that people hold aside from focusing on the concept of sustainability consciousness which brings together notions of knowingness, attitudes, and behaviors across the three dimensions of sustainable development: the environmental, social, and economic aspects.

Education for sustainable development perceptions have different objectives and they have ascertained them with full potential as how school principals ideally conceived them. These salient points covered different aspects of social development, environmental protection and economic growth analogous to clean water and sanitation, no poverty, zero hunger, gender equality, quality education, highly sustainable school, affordable and clean energy, decent work and economic growth, industryinnovation and infrastructure, reducing inequality, good health and well being, sustainable cities and communities, responsible consumption and production, climate action, life below water, green community, peace, justice and strong institutions, partnership for the goals, interrelationships and interconnectedness.

From a practical perspective, the current findings have implications for school principals to promulgate environmental literacy capability seminar-workshop concentrating on environment-economic-social inter disciplinarity and sustainable development in schools with the active collaboration of parents, teachers, and stakeholders. It is considered as one of the best practices to maintain and sustain ecological resiliency by promoting millennium development goals trough education for sustainable development. Additionally, the carbon reduction program may be integrated in the School Improvement Plan with corresponding budget taken from the Maintenance and other Operating Expenses (MOOE) allocations for government schools.

The findings were attested by the statements of principals, "The infusion should be interactive in all subjects. ESD must be incorporated in all subjects and most importantly the approach should be experiential in nature. Lecture method is good but there should be active involvement especially among students". Further, the "Principals need to undergo symposia and conferences in terms of increasing education for sustainable development perceptions through this measures we can guarantee that gaps are identified. SMBWins in our division is encouraging everyone to be 3 stars.

The result conforms the study of Bonete (2014) that principals need Education for Sustainable Development (ESD) as part of the curriculum across all subject areas. This means including key sustainable development issues into teaching and learning, climate change, disaster risk reduction, biodiversity, poverty reduction, and sustainable consumption. It also requires participatory teaching and learning methods that motivate and empower learners to change their behavior and take action for sustainable development. Education for Sustainable Development consequently promotes competencies like critical thinking, imagining future scenarios and making decisions in a collaborative way.

Additionally, it is also be in accordance with Ohman (2016) that it is essential for principals to adopt the concept of education for sustainable development contents since it covers diversed disciplines: climate change, poverty reduction, consumption and interdisciplinarity is crucial to understand the complexity of sustainable development issues which is a holistic approach since it includes multiple perspectives on content. Education for sustainable development emphasizes the necessity to include all three dimensions (environmental, social, economic) and focus on their interrelationship, as well as interactions over time and space. The holistic perspective of sustainable development recognizes that social and cultural factors are often the cause of environmental problems, and there is often a conflict of interest between economic, social, and environmental goals of individuals as well as societies.

Wals (2014) complies with that principals must explore the beauty of integrating education for sustainable development activities in schools especially in teaching and learning. Education for sustainable development focuses on the development of skills and action competence for sustainability. Education for sustainable development focuses on reflecting on issues. This progressive and transformative pedagogical approach develops students' critical evaluation of alternative perspectives and calls for learner-centered teaching strategies (e.g., critical thinking, participatory decision making, value-based learning, and multimethod approaches; and social learning. Essentially, Education for sustainable development aims to facilitate learning in such a way that learners understand the world based on their own observations, and develop competences to take action for sustainability. 
With respect to age, there is "High" level of education for sustainable perception among the four age groups as below 25 years old as top of the rank with $\bar{x}=3.78, s d=0.80$ followed by $36-45$ yrs old $(\bar{x}=3.73, s d=0.77)$, $46-55$ yrs old and above 55 years old with $\bar{x}=3.56, s d=0.81$ and $\bar{x}=3.56, s d=0.79$, respectively. However, age 26-35 yrs old had "moderate" level climate change mitigation awareness with $\bar{x}=3.31, s d=0.97$. This means that principals from particular age groups are upgraded with the latest trends on how to infuse education for sustainable development in their management.

They complied with DepEd rules on SBM was in schools through clean water and sanitation, active in promoting highly sustainable school, participate in school activities that promote good health and well being and intensify gulayan sa paaralan for a green school community.

Consequently, principals from the ages 26-35 years old have "moderate" level of education for sustainable development perceptions and are attributable to the factors. They are still new to the positions thus they find it difficult to comply with all the standards of SBM Wash in Schools for clean water and sanitation, promoting highly sustainable schools need environmental scanning of the previous existing years for assessment and evaluation, "gulayan sa paaralan" for upgrading green school community need sustainability planning - thus minimal years of existence is the solitary factor for its effectiveness and efficiency. This was supported with the idea of principal stating that "In terms of age I always believe that if one is educated enough to protect nature and more exposures to environmental advocacies then the relationship is directly proportional. Sexual orientation, precisely. Geographical location most citizens who dwell with the city life may also correlate to the idea and lastly, evaluations definitely especially if the variable is already part of the tool".

The result complied with the study of Tilbury (2015) that education for sustainable development perceptions focused on economic and social issues motivate leaders regardless of age into anthropocentric world views turning them on with ecocentrism. When leaders are exposed to holistic approach of environmental protection, greater knowingness of environmental issues are the end results. Living a life eco-centeredness can be manifested and felt in their own particular environment.

Gough (2012) abide by that age specificity effects on education for sustainable development perceptions varies on the exposure on oneself to environmental issues and advocacies. The more experienced the leader is the more knowledgeable he is in dealing with issues pertaining to the environment. Age will never be an indicator of improving ones perceptions of education for sustainable development.

The table further showed that homosexuals $(\bar{x}=3.69, s d=0.88)$ and heterosexuals $(\bar{x}=3.58, s d=0.80)$ have "High" level of education for sustainable development perception while bisexuals have "Moderate" $(\bar{x}=3.31, s d=0.75)$ level of perception. Pathologically speaking bisexuals are mentally unstable in terms of decision making thus it also affect their firmness in insinuating their stance on education for sustainable development perceptions. The confusion mechanism affected their personal views on this matter.

It can be implied that in terms of climate change mitigation awareness bisexual principals focus more on discovering their true identity whether they will settle on matrimony or solitary life. Environmental literacy is the second priority. As they perform their noble mission as school principals issues on personal formation and emotional stability validated by their true identities are their focus as school managers.

Findings of the study were attested by principal-participants that "Orientation of the person affects Climate Change Mitigation the more they spray the more they contribute to the destruction of the planet earth. We do have saloons who are using aerosols spray for hair enhancement- they should undergo orientation and seminar on how to counteract this habit of aerosols spraying in the hairs. Since homosexuals in the parlors contribute in the increasing level of carbon footprint, they should be properly oriented on responsible beauty enhancement practices that stops using of aerosols". Further, "Homosexuals interest in life were concentrated more on their love life once they are in the state of relationship, environmental awareness will never be a priority. They will do more to have money thus they do sometimes overtime in the parlors just to have something for their lover. Thus, spraying of aerosols mean more customers and may lead to more income for their lovers".

The findings conform the study of Fischgrund (2012) that "bisexual visibility" and inclusion continues to be a challenge for many workplaces. "Bi workers" feelings that they cannot bring their full selves to work and be open about their identities always affect their decesion making thus they emerged as undecided and unproductive. Negative, discriminatory attitudes and portrayals of bisexual people are commonplace. Remember - B is part of LGBTQ.

The principals have "High" level of perception across geographical locations. With Urban as $(\bar{x}=3.52, s d=0.74)$ and Rural $(\bar{x}=$ $3.61, s d=0.84)$. This means that they are fully oriented on the benefits of DepEd mandates on SBM wash in schools via clean water and sanitation, active in promoting highly sustainable school, participate in school activities that promote good health and 
well being and intensify gulayan sa paaralan for a green school community. This implies that school principals from the urban and rural areas are aiming for excellent schools based on the concept of education for sustainable development. They practice school based management with evidenced based achievements and accolades.

The finding negates the research of UNESCO (2012) that geographical location is not generally similar in terms of teachings of sustainable development concepts since each place can have choices of interests using different scales, in search of an integrated development that would include the social, environmental, and economic dimensions.

Additionally, Jensen (2015) observed that principals who are excellent leaders are transitioning a school towards education for sustainable development that requires a holistic reform of a school's operation, including its curriculum, teaching, culture, resource management and collaboration within and outside the school boundaries. Sustainability principles and practices also need to be embedded in school culture, internal and external relationships, and the resource usage, including energy, water and paper consumption.

Spring (2012) explicitly affirmed that embedding sustainability principles and values across all curriculum areas, expanding pedagogical approaches to include experiential, outdoor and action learning, and creating participatory and democratic decision-making structures that engage the whole school community are ideals that have been identified as part of whole school sustainability approaches.

In terms of RPMS-PPST rating principals with outstanding $(\bar{x}=3.54, s d=0.78)$, very satisfactory $(\bar{x}=3.62, s d=0.81)$, and satisfactory $(\bar{x}=3.46, s d=1.12)$ ratings have "high" level of education for sustainable development perceptions. This means that principals from all RPMS-PPST Ratings support the education for sustainable development with the provisions of the Philippine Constitution, Presidential Decree, and several Memorandum from the Department of Education such as Presidential Decree 1152, Republic Act No. 9512, DepEd Order No. 52, s. 2011, DepEd Order No. 72, s. 2003, and DepEd Memorandum No. 133, s. 2014. It is a challenge to educators as well to the school administrators to cultivate political, social, and moral responsibility of caring for the environment of the students in order to attain and sustain the benefits of engaging in sustainable development.

Table 3. Level of Education for Sustainable Development of principals.

\begin{tabular}{|c|c|c|c|c|c|}
\hline & $\bar{x}$ & $s d$ & Description & \multicolumn{2}{|l|}{ Legend: } \\
\hline \multicolumn{4}{|l|}{ Age } & Scale & Description \\
\hline Above 56 yrs old & 3.56 & 0.79 & High & $4.21-5.00$ & Extremely high \\
\hline $46-55$ yrs old & 3.56 & 0.81 & High & $3.41-4.20$ & High \\
\hline $36-45$ yrs old & 3.73 & 0.77 & High & $2.61-3.40$ & Moderate \\
\hline $26-35$ yrs old & 3.31 & 0.97 & Moderate & $1.81-2.60$ & Low \\
\hline Below 25 yrs old & 3.78 & 0.80 & High & $1.00-1.80$ & Extremely low \\
\hline \multicolumn{6}{|l|}{ Sexual Orientation } \\
\hline Heterosexual & 3.58 & 0.80 & High & & \\
\hline Homosexual & 3.69 & 0.88 & High & & \\
\hline Bisexual & 3.31 & 0.75 & Moderate & & \\
\hline \multicolumn{6}{|c|}{ Geographical Location } \\
\hline Urban & 3.52 & 0.74 & High & & \\
\hline Rural & 3.61 & 0.84 & High & & \\
\hline \multicolumn{6}{|l|}{ RPMS-PPST Rating } \\
\hline Outstanding & 3.54 & 0.78 & High & & \\
\hline Very Satisfactory & 3.62 & 0.81 & High & & \\
\hline Satisfactory & 3.46 & 1.12 & High & & \\
\hline Total & 3.58 & 0.81 & High & & \\
\hline
\end{tabular}

Significant Differences in Carbon Footprint Status of Principals when Grouped According to Age, Sexual Orientation, Geographical Location and RPMS-PPST Rating

As reflected in Table 4, there is no significant difference in the carbon footprint status of principals in terms of geographical location $(t=0.758$, $p$-value $=0.449$ ). This means that carbon footprint status does not affect whether the principal lives in the rural or urban areas. There were other several factors that cause carbon footprint. This result can be attested by the principal "In 
schools like Metro Manila, the principals should have higher levels of carbon footprint status rather than principals working in the provinces".

The findings negate the study of Qi Y (2012) that geographical location is significantly correlated with carbon emissions for urban places since their daily commuting contributes the second biggest proportion to household carbon emissions. Continuing growth in urban population due to rural-to-urban migration and natural growth, aging of the population, increasing car-holding, household income and living area are expected to push household carbon emissions to higher levels in the next decade.

Additionally, Meier (2012) fulfills that carbon emission from urban households are important contributor to overall carbon emissions and an integral part of carbon mitigation on the national, regional and municipal scales. Carbon emissions of urban households can be expected to maintain an increasing trend with the ongoing process of urbanization and economic development in the next decade. It is of great significance and urgency to take action to control carbon emissions, given the irreplaceable strategic significance to maintain the sustainability of economic development and mitigate carbon emissions.

Table 4. T-test Result of Carbon Footprint Status With Respect to Geographical Location

\begin{tabular}{llllllll}
\hline $\begin{array}{c}\text { Geographical } \\
\text { Location }\end{array}$ & $\overline{\boldsymbol{x}}$ & sd & $\boldsymbol{t}$ & df & Sig & Decision & Interpretation \\
\hline \hline Urban & 3.55 & 0.91 & $0.758^{\text {ns }}$ & 208 & 0.449 & Failed to Reject $\mathrm{H}_{\circ}$ & Not Significant \\
Ruran & 3.64 & 0.82 & & & & & \\
\hline \hline
\end{tabular}

Meanwhile, the level of carbon footprint status is not significant with respect to age and sexual orientation. However, there is significant difference in the level of carbon footprint status in terms of RPMS-PPST Rating ( $f=4.486, p$-value $=0.012)$ as shown in Table 5. The results mean that age and sexual orientation do not matter in the principals carbon footprint status. There are other factors associated in tge increase and decrease of their emissions as they perform their work as principals.

The findings were attested by the principal-participants stating that "I always believed that when a person grows older, his responsibility for lowering down his carbon footprint status is remarkable due to his experiences and learnings in life he is more careful and concerned with mother nature. Environmental maturity happens when a person shows interconnectedness with himself and the ecological concept of life. He is more attached to the emotions of planet earth when a tree was cut without permission, when the sea is polluted without any reason and when another land area is being developed into a subdivision when it was an agriculatural field before - he is more of a steward than a consumer". Moreover, "On sexual orientation's role with carbon footprint connotes urgency with integration of life and the atmosphere. A person's orientation sexually will never depend on his ways and means to lower down his carbon footprint. It is more on individual commitment and dedication to protect his environment whether male, female, bisexuals, homosexuals and transgender".

The result negates the study of Shegitome (2014) that age is a telling predictor of carbon dioxide emissions. Carbon footprint declines as the person grows older. Grey hair could be a sign of a green lifestyle. A person's contribution to climate change drops after age 55 as they near retirement and passive.

Long (2019) keeps to the longer term, as more and more people will be older than 55, emissions are expected to decrease. This is partially related to the fact that people at older ages produce less emissions and that a reduction of the proportion of people in the labor force tends to slow the growth in the size of the economy, and thus consumption and emission.

Yuan (2015) conforms that according to age groups, the age group of 55 years and above are the most environmentally friendly group in terms of carbon footprint since they are fulfilled and satisfied with life's circumstances thus they need to love nature by embracing an environementally rersponsible citizen.

On the other lens, United Nations (2014) holds to that gender equality and climate change, asserts universalized gender differences, untempered by ethnicity, class, culture or sexual orientation: Women and men experience different vulnerabilities and cope with natural disasters differently. Feminist organizations, which aim for gender main streaming within climate science and policy, may inadvertently be mainstreaming gendered heteronormativity and homophobia by erasing queer people from consideration.

Harding (2016) expounded that perhaps it is possible to foster an insurgent vulnerability that does not entrench gender polarities but instead endorses biodiversity, cultural diversity, and sexual diversity, and recognizes in-habit transcorporeal interchanges, processes, and flows. 
On the other hand, results reflected that there was significant difference in the level of carbon footprint status in terms of RPMSPPST Rating. This means that as carbon footprint status are significant indicators for RPMS-PPST Ratings among principals. The higher the ratings the higher the carbon footprint status. The lower the rating, the lower the carbon footprint status.

The result was attested by the principal, "When we aim for excellence in the workplace we badly need maximum energy to sustain our work thus it requires carbon footprint usage ranging from gasoline and eating meat products. Workers have to be aware that for them to be responsible in offsetting carbon footprint they must regulate their habits without sacrificing quality and excellent work outputs. Passing requirements need to be done as whole to save energy, if possible incorporating the habit of proof reading before submission saves carbon footprint since it doesnt encourage editing and repetitions".

The investigation conforms the study of Barette (2011) that excellent ratings for supervision and administration greatly affect carbon footprint among schools. Schools have special roles to play in reducing emissions. Through the curriculum and through their practices, schools can set an example to today's children and young people.

Bowers (2013) defended that schools have the potential to become beacons of good practice for their communities and to inspire positive sustainable behaviors, not just through their teaching but through also their management and their engagement with local communities.

Hence, the null hypotheses that there is no significant differences in the level of carbon footprint status when grouped according to age, and sexual orientation are accepted at $5 \%$ level of significance while null hypothesis that there is no significant difference in the level of carbon footprint status in terms of RPMS-PPST Rating was rejected.

Table 5. ANOVA Result of Carbon Footprint Status

\begin{tabular}{lcccll}
\hline & $\boldsymbol{d} \boldsymbol{f}$ & $\boldsymbol{F}$ & Sig & \multicolumn{1}{c}{ Decision } & Interpretation \\
\hline \hline Age & 4 & 1.577 & 0.182 & Failed to Reject $\mathrm{H}_{\circ}$ & Not Significant \\
Sexual Orientation & 2 & 1.544 & 0.216 & Failed to Reject $\mathrm{H}_{\circ}$ & Not Significant \\
RPMS-PPST Rating & 2 & 4.486 & 0.012 & Reject $\mathrm{H}_{\circ}$ & Significant \\
\hline \hline
\end{tabular}

Significant Differences in Climate Change Mitigation Awareness of Principals When Grouped According to Age, Sexual Orientation, Geographical Location and RPMS-PPST Rating

As shown in Table 6, there is no significant difference in the level of climate change awareness with respect to geographical location $(t=0.282$, $p$-value $=0.778$ ). Results revealed that geographical location does not affect your climate change mitigation awareness. There are several factors that increases or decreases principals consciousness in terms of climate change. This can be implied that school principals climate change mitigation awareness can be formulated based on their education and training in terms of environmental preservation not by geographical location. The preconceived ideas about climate change mitigation awareness were based on existing lectures, seminars and workshops initiated by the Department of Education.

This is further attested that "It made me realize after this Focus Group Discussion that your geographical location whether rural or urban will not matter your awareness on climate change mitigation since in this technology driven society, people can learn all the ways on how to increase climate change awareness so much more in the global arena. Understanding climate change is an international concern not just people in the rural or urban area".

The result negates the study of Artz (2015) that given urban places will have to be active in the global fight against climate change if it is to be effective. Moreover, low carbon initiatives at the city scale could generate knowledge and innovations that can have wider economic and social benefits, in addition to inspiring climate action in other cities and at a national scale.

Consequently, the findings be in accordance with Dangermond (2010) that cities have some freedom to act, particularly in contexts of decentralised governance, their capacity to act could be significantly enhanced with more supportive and effective multi-level governance arrangements on how to reduce carbon footprint. 
Table 6. T-test Result of climate change awareness with Respect to Geographical Location

\begin{tabular}{llllllll}
\hline $\begin{array}{c}\text { Geographical } \\
\text { Location }\end{array}$ & $\overline{\boldsymbol{x}}$ & sd & $\boldsymbol{t}$ & df & Sig & Decision & Interpretation \\
\hline \hline Urban & 3.55 & 0.90 & $0.282^{\text {ns }}$ & 208 & 0.778 & Failed to Reject $\mathrm{H}_{\circ}$ & Not Significant \\
Ruran & 3.59 & 0.94 & & & & & \\
\hline \hline
\end{tabular}

Moreover, Table 7 indicates that there are no significant differences in the level of climate change mitigation awareness with respect to age $(F=2.081$, $p$-value $=0.085)$, sexual orientation $(F=2.229$, $p$-value $=0.110)$, and RPMS-PPST Rating $(F=0.218, p$ value $=0.804)$. The results revealed that the climate change mitigation awareness of school principals is not affected by age, sexual orientation and RPMS-PPST Ratings. Due to mandate of school-based management in promoting Wash in Schools, Gulayan sa Paaralan and Brigada Eskwela, principals we given orientation on how to increase their own levels of awareness in terms of climate change mitigation. This implies that principals are competent to lead a school anchored on environmental resiliency and ecological consciousness.

According to the principals, Department of Education in the $21^{\text {st }}$ century is already equipped with climate change mitigation programs for sustainability of public schools in the Philippines. The school principals are also empowered to implement such programs according to its level of readiness, dedication and commitment.

The findings conform with the study of O'Neil (2010) that age relations do not matter to environmental knowledge, attitudes, and behavior. Most studies have reported negative associations of age with environmental attitudes and concern, indicating that younger people tend to be more concerned with environmental problems such as climate change.

Bamberg (2017) conforms that studies have examined the potential role of performance rating level as school principal as an indirect correlate-e.g., through environmental knowledge, attitudes, or concern-and direct correlate of pro-environmental behavior.

Hence, the null hypotheses is accepted at $5 \%$ level of significance.

Table 7. ANOVA Result of Climate Change Awareness

\begin{tabular}{lccccc}
\hline & $\boldsymbol{d f}$ & $\boldsymbol{F}$ & Sig & Decision & Interpretation \\
\hline \hline Age & 4 & 2.081 & 0.085 & Failed to Reject $\mathrm{H}_{\circ}$ & Not Significant \\
Sexual Orientation & 2 & 2.229 & 0.110 & Failed to Reject $\mathrm{H}_{\circ}$ & Not Significant \\
RPMS-PPST Rating & 2 & 0.218 & 0.804 & Failed to Reject $\mathrm{H}_{\circ}$ & Not Significant \\
\hline \hline
\end{tabular}

Significant Differences in Education for Sustainable Development Perception of Principals When Grouped According to Age, Sexual Orientation, Geographical Location and RPMS-PPST Rating

As shown in Table 8, there is no significant difference in the level of education for sustainable development with respect to geographical location $(t=0.781, p$-value $=0.435)$. Geographical location of school principals in the Island of Panay does not matter in their perceptions in terms of education for sustainable development as they perform their noble work in inspiring and training teachers to be school managers and instructional leaders in the future. This implied that whether urban or rural, principals are knowledgeable enough to implement projects with education for sustainable concepts. These are evident from the integration of the national contest entitled "Search for Eco-School and Sustainable Campus".

Principals who live in different geographical locations can update themselves with what is happening in the ESD through the internet and international journals. Nowadays e-learning can help school managers be competitive and receptive in the needs of time especially educational endeavors.

The result negates the study of Somerville (2012) since education for sustainable development is the process of equipping students with the knowledge and understanding, skills and attributes needed to work and live in a way that safeguards environmental, social and economic wellbeing, both in the present and for future generations. 
This means that the null hypothesis is accepted at $5 \%$ level of significance.

Table 8. T-test Result of Education for Sustainable Development Perception with Respect to Geographical Location

\begin{tabular}{llllllll}
\hline $\begin{array}{c}\text { Geographical } \\
\text { Location }\end{array}$ & $\overline{\boldsymbol{x}}$ & sd & $\boldsymbol{t}$ & df & Sig & Decision & Interpretation \\
\hline \hline Urban & 3.52 & 0.74 & 0.781 & 208 & 0.435 & Failed to Reject $\mathrm{H}_{\circ}$ & Not Significant \\
Ruran & 3.62 & 0.84 & & & & & \\
\hline \hline
\end{tabular}

Table 9 indicates that there are no significant differences in the level of education for sustainable development perception with respect to age $(F=0.981$, $p$-value $=0.419)$, sexual orientation $(F=0.840, p$-value $=0.433$, and RPMS-PPST Rating $(F=0.286$, $p$ value $=0.752$ ). The mindset of 'sustainability' is traced by the principals environmental protection concepts both nature and nurtured, it negates factors like geography, sex, experience and performance in embedded in the job description.

Education should provide people with scientific facts, but the major challenge is to facilitate their value reflections and decisionmaking competences - in their everyday lives and as participants in a societal learning process regarding sustainable development.

Education for sustainable development can be learned, re-learned and un-learned. The programs of education for sustainable development have already promulgated by Department of Education for replications by the school heads all over the nation. Several factors can contribute to its success and are evident among the different divisions since the positive impact of its implementation can be felt by the whole school system.

The findings were attested that "Theoretically speaking yes but they need to be experiential. In terms of age I always believe that if one is educated enough to protect nature and more exposures to environmental advocacies then the relationship is directly proportional. Sexual orientation, precisely. Geographical location most citizens who dwell with the city life may also correlate to the idea and lastly, evaluations - definitely especially if the variable is already part of the tool".

One principal said that "Obviously yes. Excellent schools in the country always have Education for Sustainable Development infusion into their curriculum thus outputs are also evaluated if they adhere to the mandate. ESD is holistic and transformational education which addresses learning content and outcomes, pedagogy and the learning environment. It achieves its purpose by transforming society". Moreover, "YES. Not only in school but in all division. One way to educate schools in terms of environmental involvement is to allow to them to expose to several projects. Exposure matters most. That increases awareness. A creation of coordinator in the school focusing only on calculating carbon footprint will be a highly commendable initiative".

The findings conform the study of Atkinson (2014) that anyone new to the concept of sustainable development who wants to understand its foundations and its relevance to their life and work practices sustainability and global values. Sustainable development practitioners - as well as private-sector actors, such as those who work in corporate sustainability and responsibility - who want a concise overview of the latest developments in the field.

Vare (2016) stated that education for sustainable development aims at providing every human being with the opportunity to acquire the knowledge, skills, attitudes and values necessary to shape a sustainable future. It also requires participatory teaching and learning methods that motivate and empower learners to change their behaviour and take action for sustainable development.

Wals (2016) stated that education for sustainable development empowers learners to take informed decisions and responsible actions for environmental integrity, economic viability and a just society, for present and future generations, while respecting cultural diversity. It is about lifelong learning, and is an integral part of quality education.

Hence the null hypotheses are accepted at $5 \%$ level of significance.

Table 9. ANOVA Result of Climate Change Awareness

\begin{tabular}{lccccc}
\hline & $\boldsymbol{d f}$ & $\boldsymbol{F}$ & Sig & Decision & Interpretation \\
\hline \hline Age & 4 & 0.981 & 0.419 & Failed to Reject $\mathrm{H}_{\circ}$ & Not Significant \\
Sexual Orientation & 2 & 0.840 & 0.433 & Failed to Reject $\mathrm{H}_{\circ}$ & Not Significant \\
RPMS-PPST Rating & 2 & 0.286 & 0.752 & Failed to Reject $\mathrm{H}_{\circ}$ & Not Significant \\
\hline \hline
\end{tabular}

Significant Difference in Education for Sustainable Development Perceptions of Principals Among the Levels of Carbon Footprint Status 
Table 10 exhibits the significant difference in the level of education for sustainable development perception among the levels of carbon footprint status. It is shown that there is significant difference in the variables with F-value is 2.501 and $p$-value is 0.044 . This means that education for sustainable development is significantly associated with carbon footprint status. They are interlinked with each other since low carbon footprint status is an indicator of sustainable school.

From a practical perspective, the current findings have implications for school principals to conceptualized an eco-school toolkit. These highlights lowering or carbon footprint and adapting sustainable schools for school managers. This will be a breakthrough in environmental literacy and ecological resiliency. The active collaboration of parents, strong synergy of stakeholders, passionate cooperation of teachers and sincere participation of the students will result into an eco-school campus for an ecoschool nation.

Carbon Footprint Status makes sustainable development an urgent priority. Sustainable development is impossible without learning. According to the principals, "Yes of course if you have ESD in your heart everything follows. You know if they are educated enough, they will do everything to save the environment". Further, "They might be intellectually equipped but they are not motivated by heart then it's still useless. He has professionals with PhD and all but reality checking its still the key". Moreover, "You know is it that we need to be federalism. It saves carbon footprint and its also friendly with ESD. Look at Makati City, weekends minimal people but weekdays full of workers. In the morning we are 4million and at night they all go to their homes. They contribute to increase carbon footprint lookout the traffic in EDSA? That's why".

The result conforms the study of Field (2017) that sustainable development something we can achieve in isolation. The air we breathe, the food we eat and the clothes we wear link us to people, environments and economies all over the world. The decisions we make on a daily basis have a global impact especially reducing our carbon footprint status. Schools, through their curriculum, campus and community, can help pupils to make sense of the complexity of our world and their place in it.

Howes (2015) observed that the Department for Education is committed to sustainable development and believes it is important to prepare young people for the future. Our approach is based on the belief that schools perform better when they take responsibility for their own improvement. We want schools to make their own judgments on how sustainable development should be reflected in their ethos, day-to-day operations and through education for sustainable development. Those judgments should be based on sound knowledge and local needs.

Krapivin (2015) followed that multiple sources of evidence suggest that being a sustainable school raises standards and enhances young people's well-being. Research supports the idea that sustainable schools engage young people in their learning, thereby improving motivation and behavior, and also promote healthy school environments and lifestyles. Saving resources such as energy and water can also save schools significant sums of money. Being responsible in one's carbon footprint status and ecological footprint is one way of connecting ourselves with nature. There are also physical and psychological benefits related to walking or cycling to school, eating more healthily and spending time in nature.Lumley (2012) revealed that principals need to visibly endorse action to reduce carbon emissions. They don't need to do the work themselves, but without their support it is unlikely that sustainability will be embedded in the school. Stone (2015) adhered to sustainable practices at the workplace needn't be expensive, time-consuming or taking ages to implement. On a smaller scale, teams can endeavour to reduce trips by vehicles outside the office. On a team-by-team basis, a firm can reduce its carbon footprint and significantly contribute to global sustainability goals. Wheeler (2012) match up to introducing the concept of ecological footprint in early childhood education may be an effective way to educate children, staff and parents on the links between the food they eat, land usage and environmental impact.

Hence the null hypothesis of no significant difference is rejected.

Table 9. ANOVA Result for Sustainable Development Perception of Principals among Levels of Carbon Footprint Status

\begin{tabular}{lrrrrrrl}
\hline $\begin{array}{l}\text { Sources of } \\
\text { Variation }\end{array}$ & \multicolumn{1}{c}{ SS } & \multicolumn{1}{c}{$\boldsymbol{d f}$} & MS & $\boldsymbol{F}$ & Sig & Decision & Interpretation \\
\hline \hline Between Groups & 6.338 & 4 & 1.584 & 2.501 & 0.044 & Reject $\mathrm{H}_{\circ}$ & Significant \\
Within Groups & 129.886 & 205 & 0.634 & & & & \\
Total & 136.224 & 209 & & & & & \\
\hline \hline
\end{tabular}

Significant Difference in Education for Sustainable Development Perceptions of Principals Among the Levels of Climate Change Mitigation Awareness

As indicated in Table 10, there is significant difference in the level of education for sustainable development perception among the levels of climate change mitigation awareness of principals given the $\mathrm{F}$-value $=3.875$ at $\mathrm{p}$-value $=0.005$. The results signify 
that education for sustainable development is significantly associated with climate change mitigation awareness of principals. They are closely interlinked and interdisciplinary inclined.

Climate change mitigation awareness is a positive indicator of sustainable schools. Principals who have "high" level of consciousness are principals who sustainable in terms of environmental protection and preservation.

From a practical perspective, the current findings have implications for school principals to create an eco-school toolkit. This highlights increasing the awareness of principals in terms of climate change mitigation and adapting sustainable schools for school managers. This will be a breakthrough in environmental literacy and ecological resiliency. The active collaboration of parents, strong synergy of stakeholders, passionate cooperation of teachers and sincere participation of the students will result into an eco-school campus for an eco-school nation.

Climate change is the greatest public policy issue of our time. If humanity is to respond to the challenges, education has a key role to play in promoting understanding and helping individuals, society and governments to make informed choices. This is not simply about giving people information, but ensuring that education - and schools specifically - is mobilized to re-orient society towards sustainable practices.

Climate change and the vision of a sustainable development have given education a new, expanded horizon: We must be capable of forward thinking: Sustainable development requires planning. We must be capable of global thinking: We need to think beyond our own little part of the world and society. We have to learn how to cope with this increased complexity. And we have to expand the sociological imagination to understand how global events affect our lives. We must be capable of understanding and taking into account common interests in the broadest sense: Climate change and sustainable development challenge us both intellectually and ethically. Sustainable development is about also being able to consider the consequences of our actions.

The result was attested by the statements principals, "The perceptions of principals are very idealistic When you are educated, you can mitigate climate change. Just to create clearance on the questions, if you are not aware that you are educated you cannot mitigate climate change. Temperature rising, sea level, flood and rainfall, are the variables if principals are not aware they couldn't innovate. If you define educated - you cannot say that you don't have the heart. Thus, it needs a "heart" to be earth-friendly". Further, "Green architecture helps. Using materials made of recycled glass in buildings are useful. Buildings dominated with glass consumes lesser amount of energy. No need of maximum lightings. There's a seal of environmental protection. Zuellig Building in Makati Avenue they are using green architecture. Maximizing the heat of sun, as source of energy and not air conditioning". Also, "When we develop material there should be infusion of ESD and Climate Change Awareness and take note it has to be mitigated. Climate change has problems and it also have opportunities". And, "Millennials need be inculcated with ESD and Climate Change. World Bank doesn't support oil businesses, they don't have grants or loans for oil corporations".

The finding conforms with the study of Kolleck (2016) that education is considered an essential tool for achieving sustainabilityrelated goals. In this regard, education for sustainable development (ESD) and climate change education (CCE) have become prominent concepts. The central characteristics of both concepts influence the non-hierarchical network governance structure that has formed around them: (1) their international origin, (2) the conceptual ambiguity that surrounds them, and (3) the limited implementing power of international organizations who developed these concepts.

Schmidt (2016) meets education for sustainable development (ESD) is an approach to teaching and learning based on the ideals and principles that underlie sustainability and applicable to all types, levels and settings of education. As such, ESD promotes multi-stakeholder social learning; emphasizes the empowerment of communities and citizens; engages with key issues such as human rights, poverty reduction, sustainable livelihoods, environmental education and gender equality in an integral way; and encourages changes in behaviour that will create a more sustainable future. Climate change education is therefore a subject that fits well within the ESD agenda.

Busch (2017) fulfills that education is a key vector to prepare societies for global changes. It plays a critical role in achieving sustainable development goals and putting into practice a global agreement on climate change. Education plays a paramount role in raising awareness and promoting behavioral change for climate change mitigation and adaption. It helps increase the climate change mitigation and adaptation capacity of communities by enabling individuals to make informed decisions.

Bangay (2014) be in accordance with principals in schools should present evidence-based findings on the factors that influence skills, attitude and behaviour change the most, in order to determine what works for formal and non-formal climate change education content, including environmental education, climate change and scientific literacy, and education for sustainable lifestyles and consumption because educational interventions are most successful when they focus on local, tangible, and 
actionable aspects of sustainable development, climate change and environmental education, especially those that can be addressed by individual behavior.

Ahlberga (2015) abided by education sector should exert effort in combating climate change. It should set forth a definition of Climate Change Education for Sustainable Development that is comprehensive and multidisciplinary and asserts that it must not only include relevant content knowledge on climate change, environmental and social issues, disaster risk reduction, and sustainable consumption and lifestyles, but also a focus on the institutional environment in which that content is learned to ensure that schools and education systems themselves are climate-proofed and resilient as well as sustainable and green. Hence, the null hypothesis is rejected.

Table 10. ANOVA Result for Sustainable Development Perception of Principals among Levels of Climate Change Mitigation Awareness

\begin{tabular}{lrrrrrrr}
\hline $\begin{array}{l}\text { Sources of } \\
\text { Variation }\end{array}$ & \multicolumn{1}{c}{ SS } & \multicolumn{1}{c}{$\boldsymbol{d} \boldsymbol{f}$} & $\boldsymbol{M S}$ & $\boldsymbol{F}$ & Sig & Decision & Interpretation \\
\hline \hline Between Groups & 9.576 & 4 & 2.394 & $3.875^{*}$ & 0.005 & Reject $\mathrm{H}_{\circ}$ & Significant \\
Within Groups & 126.648 & 205 & 0.618 & & & & \\
Total & 136.224 & 209 & & & & & \\
\hline \hline
\end{tabular}

Significant Relationships Among Carbon Footprint Status, Climate Change Mitigation Awareness, and Education for Sustainable Development Perceptions

Reflected in Table 11 is the relationship among levels of carbon footprint status, climate change mitigation awareness, and education for sustainable development perceptions. There was a significant relationship between levels of carbon footprint status and climate change mitigation awareness of principals with F-value $=0.146$ at $p$-value $=0.034$. Also, there was significant relationship between levels of carbon footprint status and education for sustainable development perception with $\mathrm{F}$-value $=$ 0.164 at $p$-value $=0.034$. Moreover, there was significant relationship between levels of climate change mitigation awareness and education for sustainable development perception with F-value $=0.225$ at $p$-value $=0.001$.

There was a strong relationship between carbon footprint status is an indicator of climate change mitigation awareness. Climate change mitigation awareness is the main framework of education for sustainable development and education for sustainable development is core foundation of carbon footprint status. This means that they all intersect with one objective which is environmental literacy and ecological resiliency.

Carbon footprint status and climate change mitigation awareness are closely interlinked. Carbon footprint status is a reliable indicator of climate change. There are several ways to combat climate change by reducing carbon footprint like recycling, utilizing less electricity, and public transportation.

Climate change mitigation awareness and education for sustainable development perceptions are related. Education for Sustainable Development is an essential element of the global response to climate change. It helps young people understand and address the impact of global warming, encourages changes in their attitudes and behavior and helps them adapt to climate change-related trends. In addition, UNESCO aims to make climate change education a more central and visible part of the international response to climate change. The programme aims to help people understand global warming today and increase "climate literacy" among young people, encouraging innovative teaching approaches to integrate climate change education in school and by raising awareness as well as enhancing non-formal education programme through media, networking and partnerships.

Education for sustainable development is related to each other with carbon footprint status. At the United Nations (UN) Sustainable Development Summit in 2015, world leaders adopted the 17 Sustainable Development Goals (SDGs). These global goals aim to address inequalities and challenges all across the planet whilst aiding development and protecting the environment by reducing carbon footprints. Meeting the target date of 2030 will require the work and co-operation of all these governments and the UN along with businesses and members of the public.

From a practical perspective, the current findings have implications for school principals to conceptualized an eco-school toolkit concentrating on the interconnectedness, interrelatedness and interrelationships of carbon footprint status, climate mitigation awareness and education for sustainable development. This will be an educational innovation in environmental literacy and 
ecological resiliency. The active collaboration of parents, strong synergy of stakeholders, passionate cooperation of teachers and sincere participation of the students will result into an eco-school campus for an eco-school nation.

Results of the study can be attributed to the statements "Definitely. One will never exist without the other, they are like part of the concept. When you mitigated climate change awareness your carbon footprint is also there". Also, "We also have to consider that CHINA is the biggest contributor of climate change. That's why two weeks ago Philippines was able to receive a grant of 500 Million US dollars to be part of green climate fund to be accessed in terms of mitigation and adaptation. They will make early warning device for natural disasters. There is lesson here, educate Philippines by revisit the interconnectedness, interrelationships and interrelatedness of carbon footprint status, climate change mitigation awareness and education for sustainable development perceptions and educate the schools starting from the principal".

The findings conform the study of Blankespoore (2010) Principals need to innovate a Curriculum for Excellence enable young learners to live adaptively in a changing culture and an increasingly unpredictable world. The programme provides experiences which help learners to build deep, rich and connected understanding of environmental and sustainability, mobilising youth action and decision making and supporting the formation of key skills for living, learning and working in a complex and changing world.

Table 11. Relationship among Carbon Footprint, Climate Change Mitigation Awareness, and Education for Sustainable Development Perceptions

\begin{tabular}{|c|c|c|c|c|}
\hline Variables & $r$ & Sig & Decision & Interpretation \\
\hline $\begin{array}{l}\text { Carbon Footprint Status and Climate Change } \\
\text { Mitigation Awareness }\end{array}$ & 0.146 & 0.034 & Reject $\mathrm{H}_{\mathrm{o}}$ & With Relationship \\
\hline $\begin{array}{l}\text { Climate Change Mitigation Awareness and } \\
\text { Education for Sustainable Development }\end{array}$ & 0,164 & 0.017 & Reject $\mathrm{H}_{\mathrm{o}}$ & With Relationship \\
\hline $\begin{array}{l}\text { Education for Sustainable Development and } \\
\text { Carbon Footprint Status }\end{array}$ & 0.225 & 0.001 & Reject $\mathrm{H}_{\circ}$ & With Relationship \\
\hline
\end{tabular}

\section{Conclusion}

The principals have low adherence towards carbon friendly habit like meatless monday, carbon friendly attitude like using ecobags in groceries, carbon friendly practice like recycling in the office, carbon friendly culture like tree planting. This may provide negative connotation on "environmental leadership" since school principals are integrally excellent in all domains of leadership as mandated by school-based management program in the department of education. Moreover, the principals have positive acceptance towards pro climate change routines like living pro-earth lifestyle, pro climate change mitigation stance like spreading of awareness, pro climate change mitigation insights of involving teachers in eco-friendly advocacies and pro-climate change mitigation belief of promoting green schools in the community. This may lead to environmental literacy and ecological resiliency since school principals have intent-oriented pro climate change behaviors. The principals also have strong affirmation on the impact of clean water and sanitation, green education, good health and wellbeing and creating sustainable community. These may propel the school towards sustainability since schools are orchestrated by impact-oriented-pro-sustainable leaders who firmly believe that ecological, societal and economic aspects of development are interlinked for school sustainability and productivity.

RPMS-PPST rating is a positive indicator of carbon footprint status. Findings revealed that principals with "outstanding" and "very satisfactory" ratings consume maximum energy and living a "carbon- unfriendly lifestyles" resulting to an increase in the carbon footprint status. This may create negative impressions among teachers that "outstanding" or "very satisfactory" principals are not manifesting carbon friendly habits, attitudes, practices and cultures. This may also a point of reference for Department of Education to revisit the RPMS-PPST evaluation tool and include environmental literacy and ecological resiliency as one of the areas to be evaluated to conform with integral-sustainable-transformational leadership in the schools. On the other hand, geographical location, age, sexual orientation and RPMS PPST Rating will not affect climate change mitigation awareness of principals. This may lead to further research in discovering other factors that significantly affect climate change mitigation awareness not just with principals particularly but with teachers and students collectively. Further, geographical location, age, sexual orientation and RPMS PPST Rating will not affect education for sustainable development perceptions of principals. This may lead to further research in discovering other factors that significantly affect education for sustainable development perceptions not just with principals particularly but with teachers and students collectively. 
Carbon footprint status is a significant indicator of education for sustainable development. This adheres to the transformationalsustainable leadership with carbon footprint consciousness. Additionally, this may lead to an affirmative interpretation that principals are living the core values of Department of Education of being "Maka-Kalikasan" creating highly carbon-friendlysustainable school evidently shown in their own specific stations.

Climate change mitigation awareness is a significant indicator of education for sustainable development. This adheres to transformational and eco-centric sensitive leadership with climate change mitigation awareness. Additionally, this commemorates success of implementation to the Department of Education since principals are in full support of the DepEd Order 52, s. 2011 which calls for strengthening environmental education in public schools with ecological responsibilities and collaborative effort.

The school principals' carbon footprint status influences their climate change mitigation awareness; their of level climate change mitigation awareness influences their education for sustainable development perceptions; and education for sustainable development perceptions influences their carbon footprint status. The findings may lead to the conceptualization of eco-school toolkit that will guide them to decrease their carbon footprint status, increase their level of climate change mitigation awareness and adopt the concept of education for sustainable development in their schools. The interconnectedness, interrelationships and interrelatedness of carbon footprint status, climate change mitigation awareness and education for sustainable development perceptions may create ecological foundations for school principals to be eco-friendly leader, serving an eco-friendly school and promoting an eco-friendly community for an eco-friendly nation.

\section{References}

[1] Ahlberga, M. (2015). Education for sustainable living: integrating theory, practice, design, and development. Scandinavian Journal of Educational Research.

[2] Al Yousuf, B. (2016). The power of education in promoting climate change awareness. Gulf News Thinkers.

[3] Artz, Matt. (2015). "Science and Our Changing Climate: GIS Creates a Framework for Research and Modeling." Redlands Daily Facts: Redlands, California.

[4] Atkinson, G., Dietz, S., Neumayer, E., Elgar, E. (2014). Introduction in handbook of sustainable development. Cheltenham, UK, 2014

[5] Bamberg, S. (2017) Twenty years after Hines, Hungerford and Tomera: A new meta-analysis of psychosocial determinants of pro-environmental behavior. Julenbourh Publising House: USA.

[6] Bangay, Colin (2014): Education responses to climate change and quality: two parts of the same agenda. International Journal of Educational Development.

[7] Bard, E., Raisbeck, G., Yiou, F., \& Jouzel, J. (2000). Solar irradiance during the last 1200 years based on cosmogenic nuclides. Tellus B, 52(3), 985-992.

[8] Barrett, J. (2011). Component ecological footprint: developing sustainable scenarios, impact assessment and project appraisal. Resource Management.

[9] Beattie, G. (2016). Explicit and implicit attitudes to low and high carbon footprint products. International Journal of Environment, Cultural, Economic and Social Sustainability, 5(4), 191-206.

[10] Bellasen, V. (2015). Accounting for Carbon Monitoring, Reporting, and Verifying Emissions in the Climate Economy. Cambridge University Press.

[11] Berners-Lee, M. (2010). What is carbon footprint. Retrieved from The Guardian: https://www.theguardian.com/environment/blog/2010/jun/04/carbon-footprint-deffintion.

[12] Blankespoor, B. (2010). Adaptation to climate extremes in developing countries: the role of education. The World Bank Development Research Group: Washington DC.

[13] Bondoc, K.P. (2016). Climate change awareness among Students in the Secondary Level. European Academic Research Vol. III.

[14] Bonete, M. (2011). Education for Sustainable Development: A Coherent Philosophy for Environmental Education. Camb. J. Educ.

[15] Bowers, C. (2013). Towards eco-justice pedagogy". Pape presented at the European Educational Research Association Conference: Edinburgh.

[16] Broody, A., J. Demetriades, and E. Esplen. (2014). Gender and climate change: mapping the linkages. UK: BRIDGE, Institute of Development Studies (IDS)

[17] Busch, K. C. (2017). Fundamental Climate Literacy and the Promise of the Next Generation Science Standards. Teaching and Learning About Climate Change: A Framework for Educators. Shepardson Publishing:London.

[18] Carbon Trust. (2014, July). Carbon Footpinting. Retrieved from Carbon Trust: http://www.carbontrust.com/resources/gyides/carbonfoot printing-and-reporting/carbon-footprinting

[19] Carslaw, K. S. (2010). Boreal forests, aerosols and the impacts on clouds and climate". Philosophical Transactions of the Royal Society A: Mathematical, Physical and Engineering Sciences.

[20] Chen, W. (2017). Assessment of Carbon Emission Reduction Potentials in Guangxi. Environmental Science and Technology.

[21] Collins, R., (2011). Carbon Offsets. In M. Shally-Jensen, Encyclopedia of Contemporary American Social Issues.

[22] Dangermond, J. (2010). The geographic approach to climate change." GeoSpatial Today: USA.

[23] Druckman, A. (2011). Mapping Our Carbon Responsibilities: More Key Results from the Survey Environemnt Lifestyle Mapping (SELMA) Framework. RESOLVE Working Paper 02-09. Surrey. 
[24] Domingo T. (2013). Rural livelihoods under stress: The impact of climate change on livelihoods in South Western Zimbabwe': American International Journal of Contemporary Research.

[25] Ekpekin, W.E. (2015). Environmental literacy awareness and information dissemination among adolescents in calabar municipality local government area secondary schools in cross Rriver atate, Nigeria. Asia Pacific Journal of Education, Arts and Sciences.

[26] FAO/UNESCO-IIEP. (2003). Education for rural development: towards new policy responses. Rome and Paris.

[27] Field, B. C. (2017). Environmental policy: an introduction. Waveland Press Inc: Illinois.

[28] Fillardo, M. (2010). State of Our Schools: America's K-12 Facilities - The Center for Green Schools; Washington, DC, USA.

[29] Folke, C. (2016). Resilience: The emergence of a perspective for social-ecological systems analyses. Global Environmental Change Publishing.

[30] Fischgrund, B. N. (2012). Conceptions of hypermasculinity and mental health states in gay and bisexual men. Psychology of Men \& Masculinity.

[31] Gough, S. (2007). Higher Education and Sustainable Development: Paradox and Possibility. Routledge: Abingdon, United Kingdom.

[32] Gough, S. (2012). Higher Education and Sustainable Development: Paradox and Possibility. Routledge: Abingdon, United Kingdom.

[33] Grubb, A., (2014). Meeting the Carbon Challenge: The Role of Commercial Real Estate Ownerss, Users \& Managers. Chicago.

[34] Haq G. (2013). Greening the Greys: Climate Change and the Over 50s. York, UK: Stockholm Environment Institute, University of York.

[35] Haq G. (2011). Growing Old in a Changing Climate. Meeting the Challenges of an Ageing Population and Climate Change. Stockholm Environment Institute: Sweden.

[36] Harding, Sandra (2016): Science and Social Inequality: Feminist and Postcolonial Issues. University of Illinois Press: Urbana, USA.

[37] Horng, J. S., Hu, M. L. M., Teng, C. C. C., Hsiao, H. L., \& Liu, C. H. S. (2013). Development and validation of the low-carbon literacy scale among practitioners in the Taiwanese tourism industry. Tourism Management, 35, 255-262.

[38] Howes, M. (2015). Politics and the environment: risk and the role of government and industry. Earthscan: London.

[39] Hsiung, J. (2010). Estimates of Global Oceanic Meridional Heat Transport. Journal of Physical Oceanography.

[40] Hua, G. (2011). Managing Carbon Footprints in Inventory Management. International Journal of Production Economics, 132(2), 178-185.

[41] Jansen, D. (2015). Education for sustainable development-building capacity and empowerment. Conference report on Education for Sustainable Development: Denmark.

[42] Jones, C., (2011). Quantifying Carbon Footprint reduction Opportunities for US Households and Communities. Environmental Science \& Technology.

[43] Jones, P. (2010) Sustainability Education: Perspectives and Practice Across Higher Education. Renouf Publishing.

[44] Jung, N. (2018). Advancing Deisgn Criteria for Energy and Environmental Performance of Buildings. Aalto UNiversity Publishing.

[45] Krapivin, V. (2015). Globalisation and sustainable development: environmental agendas. Springer/Praxis Publishing: Chichester.

[46] Kolleck, N. (2016). Uncovering Influence through Social Network Analysis: The Role of Schools in Education for Sustainable Development. J. Educ. Policy.

[47] Lang, J. (2013). How to Succeed with Education for Sustainability. Curriculum Corporation.

[48] Larry, A. (2010). Limitations of Carbon Footprint as Indicataor of Environmental Sustainability. American Chemical Society.

[49] Li, Z., and Williams, M. (2010) Environmental and Geographical Education for Sustainability: cultural contexts. Nova Publishers.

[50] Long, Y. (2014). Unequal age-based household emission and monthly variation embodied in energy consumption - A cases study of Tokyo. Yokoma Publishing House: Japan.

[51] Lumley, S. (2012). Sustainability and degradation in less developed countries: immolating the future? Ashgate: Burlington.

[52] Meehcl, A. (2012). Externally Forced and Internally Generated Decadal Climate Variability Associated with the Interdecadal Pacific Oscillation". Journal of Climate

[53] Meier T.(2012). Gender as a factor in an environmental assessment of the consumption of animal and plant based foods in Germany. The International Journal of Life Cycle Assessment: Stuttgart, Germany.

[54] Miles, G. M., Grainger, R. G., \& Highwood, E. J. (2004). The significance of volcanic eruption strength and frequency for climate. Quarterly Journal of the Royal Meteorological Society: A journal of the atmospheric sciences, applied meteorology and physical oceanography, 130(602), 2361-2376.

[55] Molina, M. (2016). The Greatest Energy Story You Haven'tHeard: How Investing in Energy Efficiency Changed the US Power Sector and Gave Us a Tool to Tackle Climate Change.

[56] New, M., (2010). "Review: Precipitation measurements and trends in the twentieth century". International Journal of Climatology.

[57] O'Flaherty, J. (2017). The impact of development education and education for sustainable development interventions: a synthesis of the research. Research in Science and Technological Education.

[58] Öhman, J. (2016). Values and Democracy in Education for Sustainable Development; Liber: Malmö, Sweden.

[59] O'Neil J. (2013). Trends in Global $\mathrm{CO}_{2}$ emissions: 2013 report. PBL Netherlands Environmental Assessment Agency: Amsterdam.

[60] Parish, Judith T. (2010). "Climate of the Supercontinent Pangea. Chemical Geology. The University of Chicago Press.

[61] Pasqualino, J. (2017). The Carbon Footprint and Energy Consumption of Beverage Packaging Selection and Disposal. Journal of Food Engineering.

[62] Pahle, G. (2011). Carbon Footprints and Embosied Carbon at Multiple Scales. Environmental Research Journal, 2(4), $245-250$.

[63] Pierce, J. R. (2017). Cosmic rays, aerosols, clouds, and climate: Recent findings from the CLOUD experiment. https://agupubs.onlinelibrary.wiley.com/doi/abs/10.1002/2017JD027475. Journal of Geophysical Research: Atmospheres.

[64] Prentice, I. (2010). Vegetation and Climate Change in Eastern North America Since the Last Glacial Maximum. Ecology.

[65] Qi Y (2012). Annual Review of Low-Carbon Development in China (2011-2012). Social Sciences Academic Press; China.

[66] Retalack, Gregory J. (2010). Cenozoic Expansion of Grasslands and Climatic Cooling. The Journal of Geology.

[67] Rohrer, J., (2014). What is Carbon Foortprint. Retrieved from Time for Change: http://timeforchange.org/what-is-a-carbon-footprint-de finition

[68] Sallafyky, N., (2015). Adaptive Management: A Tool for Conservation Practitioners. Biodiversity Support Programme, Washington DC.

[69] Safire, W. (2010). Carbon Footprint. Retrieved from The NewYork Times 
[70] Savin-Williams, R. C. (2012). Prevalence and stability of self-reported sexual orientation identity during young adulthood. Archives of Sexual Behavior.

[71] Schmidt, G.(2016). Climate Change: Picturing the Science. Norton Publishing: New York.

[72] Schrage J.H. (2008) Aging Nation: The Economics and Politics of Growing Old in America.Johns Hopkins. University Press: Baltimore.

[73] Shigitomi, Y. (2014). Changes in the Carbon Footprint of Japanese Households in an Aging Society. Environ. Sci. Technol.

[74] Sims, G. D. (2017). Sustainability Education: where does it belong? Minnesota State University. http://books.nap.edu/openbook.php?record_id=4778\&page=36" "Solar Irradiance Changes and the Relatively Recent Climate" HYPERLINK "http://books.nap.edu/openbook.php?record_id=4778\&page=R1" Solar influences on global change . Washington, D.C: National Academy Press.

[75] Smith, C. (2016). Coalition for Healthier Schools Special Issues: Climate Change. Towards Healthy Schools: Reducing Risks to Children. Healthy Schools Network: Albany, KY, USA.

[76] Solomon, S. (2010). Understanding and Attributing Climate Change. Fourth Assessment Report of the Intergovernmental Panel on Climate Change. Intergivernmental Panel on CLimate Change (IPCC).I

[77] Somerville, M.(2012). Place and sustainability literacy in schools and teacher education. Australian Association for Research in Education: Sydney, Australia.

[78] Spring, J. (2012). How educational ideologies are shaping global society: Intergovernmental organizations, NGO's, and the decline of the nation state: New York.

[79] Stern, M. (2015). Ecological literacy: educating our children for a sustainable world. Sierra Club Books: San Francisco

[80] Stone, M. (2015). Ecological literacy: educating our children for a sustainable world. Sierra Club Books: San Francisco.

[81] Sun, Y. (2016). Decomposition of Tourism Greenhouse Gas Emissions: Revealing the Dynamics Between Tourism Economic Growth, Technological Efficiency, and Carbon Emissions. Tourism Management, 55, 326-336.

[82] Tatiana, G. (2015). "Influencing Gender-Inclusive Climate Change Policies in Latin America" Journal of Gender, Agriculture and Food Security.

[83] The United Nations Intergovernmental Panel on Climate Change (2007) Climate Change Synthesis Report. Geneva, Switzerland.

[84] Taylor, K.G. (2010). Urban environmental education from a social-ecological perspective: conceptual framework for civic ecology education. Cities and the Environment: USA

[85] Tidball, K.G. (2010). Urban environmental education from a social-ecological perspective: conceptual framework for civic ecology education. Cities and the Environment: USA.

[86] Tilbury, D. (2015). A National Review of Environmental Education and Its Contribution to Sustainability in Australia: Frameworks for Sustainability; Macquarie University: Sydney, Australia.

[87] TSDEP (2014). The development and validation of a framework for teaching competencies in higher education. Education 101 Publishing. USA.

[88] Toscano, P. (2017). Save the unicorn! LGBTQ responses to climate change. The Huffington Post.

[89] Tukker, A. (2016). Environmental and resource Footprints in Global Context: Europe's Structural Deficit in resource Endowments. Global Environmental Change.

[90] UNESCO. (2012). Education for All Global Monitoring Report 2002: Is the World on Track? Paris.

[91] Vare, P. (2016). Learning for a change: Exploring the relationship between education and sustainable development. J. Educ. Sustain.

[92] Wals, A. (2014). Social Learning towards a Sustainable World: Principles, Perspectives, and Praxis. Wageningen Academic Publishing: The Netherlands.

[93] Wheeler, K. A. (2012). Education for a sustainable future: a paradigm of hope for the 21st century. Kluwer Academic Plenum Publishers: New York.

[94] Wong, S. (2016). Can climate finance contribute to gender equity in developing countries?. Journal of International Development, 28(3), 428444.

[95] Yuan, B. (2016). The effects of urbanization, consumption ratio and consumption structure on residential indirect $\mathrm{CO}_{2}$ emissions in China: $\mathrm{A}$ regional comparative analysis. Komori Publishing: Japan. 